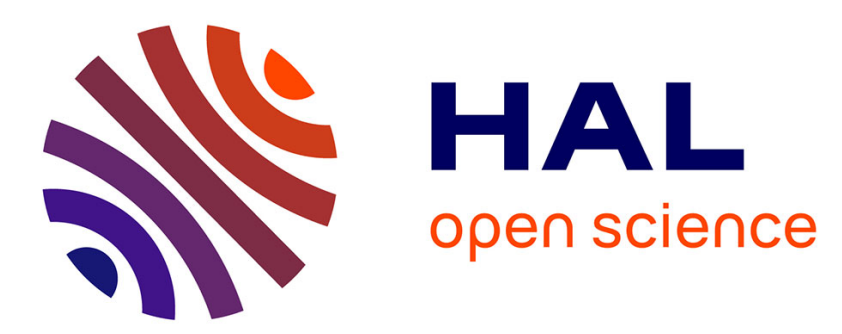

\title{
Electro-Fenton catalyzed with magnetic chitosan beads for the removal of Chlordimeform insecticide
}

S. Rezgui, A. Amrane, F. Fourcade, A. Assadi, L. Monser, N. Adhoum

\section{To cite this version:}

S. Rezgui, A. Amrane, F. Fourcade, A. Assadi, L. Monser, et al.. Electro-Fenton catalyzed with magnetic chitosan beads for the removal of Chlordimeform insecticide. Applied Catalysis B: Environmental, 2018, 226, pp.346-359. 10.1016/j.apcatb.2017.12.061 . hal-01695566

\section{HAL Id: hal-01695566 \\ https://hal-univ-rennes1.archives-ouvertes.fr/hal-01695566}

Submitted on 10 Sep 2018

HAL is a multi-disciplinary open access archive for the deposit and dissemination of scientific research documents, whether they are published or not. The documents may come from teaching and research institutions in France or abroad, or from public or private research centers.
L'archive ouverte pluridisciplinaire HAL, est destinée au dépôt et à la diffusion de documents scientifiques de niveau recherche, publiés ou non, émanant des établissements d'enseignement et de recherche français ou étrangers, des laboratoires publics ou privés. 


\section{Electro-Fenton catalyzed with magnetic chitosan beads for the removal of} Chlordimeform insecticide

\section{Soumaya Rezgui $^{\text {a,b,c*}}$, Abdeltif Amrane ${ }^{a}$, Florence Fourcade ${ }^{a}$, Aymen Assadi ${ }^{\text {, }}$,otfi Monser $^{b, c}$, Nafaa Adhoum ${ }^{c}$}

${ }^{a}$ Ecole Nationale Supérieure de Chimie de Rennes, CNRS, UMR 6226, 11 allée de Beaulieu, CS 50837, 35708 Rennes Cedex 7, France.

${ }^{b}$ Institut National des Sciences Appliquées et de Technologie, B.P. $N^{\circ} 676,1080$ Tunis Cedex, Tunisia.

${ }^{c}$ Unité de Recherche en Eléctrochimie, Matériaux et Environnement (UR16ES02), IPEIK, Université de Kairouan, Kairouan, Tunisia.

* Corresponding author: Tel.: +216 54331 379; fax: +216 71704329

E-mail address: soumaya.rezgui@insat.rnu.tn

\section{Abstract}

The degradation of chlordimeform (CDM) has been investigated by a heterogeneous electroFenton process involving magnetite supported chitosan beads $\left(\mathrm{Fe}_{3} \mathrm{O}_{4}-\mathrm{Cs}\right)$ as catalyst. The catalyst was prepared by dropwise addition of an acidic chitosan-metal salts solution into sodium hydroxide precipitation bath. SEM, XRD and FTIR analysis were used to characterize the catalysts. The effect of experimental parameters, such as the current intensity, the amount of iron on chitosan beads, the concentration of the catalyst and the initial $\mathrm{pH}$ on the pollutant removal rate was investigated. The optimal conditions for the degradation of $37.5 \mathrm{mg} . \mathrm{L}^{-1}$ initial CDM concentration were achieved at an applied cathodic current of $-5 \mathrm{~mA}$, using 0.5 g. $\mathrm{L}^{-1}$ of magnetic chitosan beads (with an average iron amount of $0.104 \mathrm{mmol}$ ) and at $\mathrm{pH}=3$. Under these conditions, CDM was effectively removed within 30 min with $80 \%$ of NPOC removal after 6 hours of treatment. The reaction followed a pseudo-first order kinetic equation. The adsorption test on the chitosan beads (with and without iron) demonstrated that the insecticide removal was solely induced by heterogeneous electro-Fenton treatment with $\mathrm{Fe}_{3} \mathrm{O}_{4}$-CS beads. In addition, the reusability of this catalyst was effectively demonstrated. Finally, LC-MS analysis allowed the proposal of a plausible degradation route.

Key words: Chlordimeform; magnetic chitosan beads; heterogeneous process; ElectroFenton. 


\section{Introduction}

Among all hazardous organic compounds found in wastewater, pesticides occupy an important place due to their high consumption in both agriculture and veterinary to control, repel and prevent pests $[1,2]$. Pesticides are known as long-term recalcitrant and very toxic compounds [3-5]; their removal from wastewater has become a challenge.

Chlordimeform $\mathrm{N}$-(4-chloro-o-tolyl)- $\mathrm{N}, \mathrm{N}$-dimethylformamidine (CDM) is a formamidine insecticide/acaricide used on crops, livestock, and pets [6]. CDM is used extensively on fruits and cotton. Its insecticidal action is caused by activation of octopamine receptors, and its toxicity in mammals is mediated by activation of alpha ${ }_{2}$-adrenergic receptors. CDM is well absorbed and rapidly metabolized to compounds of higher toxicity. Demethylated CDM has a higher acute toxicity and higher affinity for alphaz-adrenoceptors, whereas 4-chloro-otoluidine has carcinogenic properties [7].

The chemical structure of CDM is shown in Figure 1. Insecticidal formamidines, including CDM have adverse effects on human health and the environment. Toxicological tests carried out on animals at the laboratory scale showed that a long exposure to CDM can primarily affect the cardiovascular system [8].This insecticide/acaricide can cause profound changes on the visual function [9]. Furthermore, CDM is documented as human and animal carcinogen $[7,10]$. For these reasons, the application of CDM has been banned in many countries [11, 12]. However the detection of CDM residues in human adipose tissue, food and environment was reported in recent studies [13-17].

\section{Figure 1}

In the last decades, the Fenton process has been widely employed in the degradation of many persistent organic pollutants [18]. It is based on the oxidation of ferrous ions to ferric iron by hydrogen peroxide according to reaction 1 . Hydroxyl radicals $\left({ }^{\bullet} \mathrm{OH}\right)$ are one of the most stronger oxidants $\left(\mathrm{E}^{\circ}\left({ }^{\bullet} \mathrm{OH} / \mathrm{H}_{2} \mathrm{O}\right)=2.8 \mathrm{~V}\right.$ vs.SHE (Standard Hydrogen Electrode)), are nonselective and highly reactive with organic and inorganic compounds [19].

$\mathrm{Fe}^{2+}+\mathrm{H}_{2} \mathrm{O}_{2} \longrightarrow \mathrm{Fe}^{3+}+\mathrm{OH}^{-}+{ }^{\bullet} \mathrm{OH}$

Eq.1

Electrochemical Advanced Oxidation Processes (EAOPs) based on the Fenton's reaction, such as the electro-Fenton (EF) process, have attracted a great interest due to the in-situ production of hydrogen peroxide using various cathode materials such as carbon felt [20-22], tubular carbon nanotube [23], BDD plate [24], graphite [25] and activated carbon fiber [26]. 
1 The hydrogen peroxide is produced in an aqueous medium by the reduction of dissolved oxygen by an electro-Fenton process (Eq.2).

4 Hence, the electro-Fenton solves the problems of transportation and storage of this compound, which is expensive, unstable and potentially harmful.

On the other hand, to avoid problems related to the loss of dissolved iron and the production of solid sludge, recent investigations focused on the possibility of using heterogeneous catalysts [27-31]. For this purpose, magnetite $\mathrm{Fe}_{3} \mathrm{O}_{4}$ has attracted a great attention as efficient catalyst for the heterogeneous Fenton process due to its simple handling, ease of recovery with an external magnetic field, oxidative stability, biological compatibility, strong superparamagnetic behavior and its high catalytic activities [32-34]. The Fenton activity is due to the special structural characters of magnetite which has a cubic inverse spinel structure with tetrahedral and octahedral sites filled by Fe(II) and Fe(III) cations. The catalytic activity is mainly due to the octahedral cations which are almost exclusively exposed on the surface. The octahedral sites are occupied by both Fe(II) and Fe(III), allowing the Fe species to be reversibly oxidized and reduced while keeping the same structure [35, 36]. However, the use of $\mathrm{Fe}_{3} \mathrm{O}_{4}$ NPs can cause the problem of nanoparticles aggregation and the rapid degradation of magnetite onto a given biological matrix [37]. These problems can be overcome by preparation of a hybrid biocomposite using biopolymers as support.

Advantageous alternative supports including biopolymers and biomass-related polymers have been recently employed for the preparation of supported NPs. Biopolymers, such as chitosan and alginate, are indeed attractive candidates to be employed as supports for catalytic applications. They offer several advantages compared to traditional supports including low toxicity and cost, high biocompatibility, availability and abundance [38].

In the last few years, chitosan (CS) has attracted researchers' attention as a natural chelating agent for use in chemical catalysts due to its strong affinity to transition metals, its high sorption capacity, stability of metal anions and physical and chemical versatility [39, 40].

The use of appropriate supports to avoid nanoparticles aggregation, as well as the production of supported nanoparticles with higher homogeneous dispersion remains a scientific challenge as attested by the numerous recent studies dealing with this subject [38, 41]. Therefore, the aim of this study was to develop highly homogeneous magnetic chitosan beads with a good catalytic activity and stability for CDM insecticide removal by the electro-Fenton process. 


\subsection{Chemicals products}

All chemicals used were of analytical grade and used without further purification. Chlordimeform, sodium hydroxide $(\mathrm{NaOH})$ and magnetite Iron (II,III) oxide $\mathrm{Fe}_{3} \mathrm{O}_{4}$ were obtained from Sigma-Aldrich (France). Acetic acid was obtained from Acros Organics (France). Ferrous sulfate Iron (II) $\left(\mathrm{FeSO}_{4} \cdot 7 \mathrm{H}_{2} \mathrm{O}\right)$ was purchased from Prolabo (France). Iron (III) chloride $\left(\mathrm{FeCl}_{3} \cdot 6 \mathrm{H}_{2} \mathrm{O}\right)$ and sodium sulfate decahydrate were from Acros Organics. Sulfuric acid and nitric acid were supplied by Carlo Erba. acetonitrile (HPLC-grade) was purchased from Fisher Scientific (Loughborough, UK). Ultra-pure water obtained from ELGA Purelab Option-Q DV 25 system was utilized for the preparation of all working solutions, as well as HPLC and LC- MS/MS mobile phases.

\subsection{Electrochemical process}

The electrochemical heterogeneous Fenton reaction was performed in an undivided closed glass cell. The EF process was conducted in galvanostatic mode. The applied current was provided by a power supply Micolab Micronic System (Villetted'anthon, Fr), and the current was controlled and frequently regulated. The cathode was a carbon felt piece $(1.5 \mathrm{~cm}$ length, 1 cm width, $0.5 \mathrm{~cm}$ thickness) and the anode was a platinum wire. The hydrogen peroxide $\mathrm{H}_{2} \mathrm{O}_{2}$ was produced electrochemically by continuously bubbling compressed air near the cathode leading to the reduction of dissolved oxygen (DO) in acidic solutions containing dilute supporting electrolyte. The $\mathrm{pH}$ was adjusted by addition of dilute solutions of sulfuric acid or sodium hydroxide. The ionic strength was maintained constant by the addition of an inert supporting electrolyte $\left(0.05 \mathrm{M}, \mathrm{Na}_{2} \mathrm{SO}_{4}\right)$. Prior to the electrolysis, compressed air was bubbled for $15 \mathrm{~min}$ through the aqueous solutions. Samples were regularly taken to measure the insecticide concentration.

\subsection{Analytical procedures}

\subsubsection{Non-purgeable organic carbon (NPOC) measurements}

The mineralization of the chlordimeform was monitored by measuring the non-purgeable organic carbon (NPOC) abatement by TOC-VCPH/CPN Total Organic Carbon Analyzer Schimadzu. 


\subsubsection{HPLC analysis}

The measurements of the residual CDM concentration were performed by a Waters High Performance Liquid Chromatography (HPLC) system consisting of a Waters ${ }^{\mathrm{TM}} 600$ instrument, equipped with a C18 reverse-phase Column $(4.6 \mathrm{~mm} \times 250 \mathrm{~mm}, 5 \mu \mathrm{m})$, along with a 996 Photodiode array detector and a Waters 717 plus Autosampler injector. The system was controlled through an Empower program. Prior to analysis, the samples had to be filtered through a $0.45 \mu \mathrm{m}$ filter. The injection volume was set at $50 \mu \mathrm{L}$ and an isocratic eluent Water/Acetronitrile (60/40) was pumped at a flow rate of $1 \mathrm{~mL} \mathrm{~min}^{-1}$. CDM had a retention time of 10 min under these conditions and many peaks of the byproducts appeared at lower retention times. Detection was performed with a photodiode array detector Waters 996 at 240 $\mathrm{nm}$.

The detection and evolution of carboxylic acids was followed by an ion exclusion chromatography system Dionex DX120. A system equipped with a column Dionex AS11-HS $(4 \times 250 \mathrm{~mm})$ coupled to a conductivity detector was used. Separation was achieved by a gradient elution composed of a mixture of potassium hydroxide $(\mathrm{KOH})$ and water, as follows: 0-10 min (isocratic $10 \mathrm{mM}$ ); 10-25 min (gradient from 10 to $45 \mathrm{mM}$ ); 25-35 min (isocratic $45 \mathrm{mM}$ ). Flow rate was adjusted to $1 \mathrm{~mL} \mathrm{~min}^{-1}$. The injection volume was set at $250 \mu \mathrm{L}$. The system was connected with an acquisition and data treatment unit commanded by analytical Chromeleon SE software.

The determination of inorganic anions was carried out by an ion chromatography system (IC861, Metrohm) equipped with an AS4A-SC column (150 mm $\times 4 \mathrm{~mm})$. The eluents were $\mathrm{Na}_{2} \mathrm{CO}_{3}(3.2 \mathrm{mM})$ and $\mathrm{NaHCO}_{3}(1 \mathrm{mM})$ solutions pumped at a flow rate of $0.7 \mathrm{~mL} \mathrm{~min}{ }^{-1}$ and a pressure of around 2000 psi.

\subsubsection{UPLC-MS/MS analysis}

The degradation intermediates were identified through LC-MS/MS ultra-high pressure liquid chromatography (Acquity UPLC - Waters) coupled to a Waters Micromass Quattro Premier (Waters Corporation, Manchester, UK) triple quadruple mass spectrometer as detector. It was operating with an electrospray source in positive ionization mode with a cone potential of 25 $\mathrm{V}$. Analyses were performed in full scan and daughter scan modes, with a collision energy of $25 \mathrm{eV}$. Spectra were acquired between 80 and $500 \mathrm{~m} / \mathrm{z}$ and the data were treated with Micromass Mass-Lynx 4.1 software. The UPLC system (Waters Corporation, Milford, MA, 
1 USA) consists of an Acquity UPLC binary solvent manager, an Acquity UPLC sample manager and an Acquity UPLC column heater equipped with a Waters Acquity UPLC BEH Shield RP18 column $(2.1 \mathrm{~mm} \times 100 \mathrm{~mm}, 1.7 \mathrm{~mm}$ particle size) (Milford, MA, USA) maintained at $45{ }^{\circ} \mathrm{C}$. Analyses were performed using $0.1 \%$ formic acid in acetonitrile as eluent $A$ and $0.1 \%$ formic acid in a mixture of MilliQ Water/Acetonitrile (90/10, v/v) as eluent $\mathrm{B}$, delivered at a flow rate of $0.4 \mathrm{~mL} \mathrm{~min}^{-1}$. The elution gradient started with $100 \%$ of eluent B. After $1 \mathrm{~min}$, the proportion of eluent A increased linearly to $100 \%$ of A within 8 min.

\subsubsection{Determination of the iron content}

The amount of iron in the catalyst, as well as, the total leached iron was determined by atomic absorption spectrophotometry (AA140, VARIAN) whose detection limit is estimated to 3.1 $\mu \mathrm{mol} . \mathrm{L}^{-1}$. For the heterogeneous catalysts, it was necessary to obtain an iron solution by acid leaching samples of $\mathrm{Fe}_{3} \mathrm{O}_{4}$-Cs beads in concentrated hydrochloric acid solution until complete discoloration of the bead (after 12 hours).

In order to determine the molar ratio $\mathrm{Fe}^{2+} / \mathrm{Fe}^{3+}$ in $\mathrm{Fe}_{3} \mathrm{O}_{4}$ - $\mathrm{Cs}$ beads, soluble iron quantification was estimated by the standard 1,10-phenantroline spectrophotometric method [42]. 1,10phenantroline reacted with $\mathrm{Fe}^{2+}$ forming a colored complex which can be measured at a wavelength of $510 \mathrm{~nm}$. While the amount of the individual $\mathrm{Fe}^{3+}$ was calculated from the difference between the total iron and the $\mathrm{Fe}^{2+}$. The amount of total iron was estimated by the same spectrophotometric method after the addition of a reducing agent of $\mathrm{Fe}^{3+}$ to $\mathrm{Fe}^{2+}$.

\subsubsection{Determination of the zero point charge of the catalyst}

The $\mathrm{pH}$ of zero point charge $\mathrm{pH}_{\mathrm{zpc}}$ was determined by the simple method of salt addition [43]. A series of 5 suspensions were prepared by mixing $40 \mathrm{~mL}$ of sodium nitrate $\mathrm{NaNO}_{3}(0,1 \mathrm{M})$ with $0.2 \mathrm{~g}$ of sample. The $\mathrm{pH}$ of each solution in the series of $\mathrm{NaNO}_{3}$ was beforehand adjusted to 2, 6, 8, 10 and 12 using a diluted $\mathrm{HNO}_{3}$ or $\mathrm{NaOH}$ solution. Then, each flask was vigorously agitated for $24 \mathrm{~h}$. The final $\mathrm{pH}$ was measured. After this time each resulting $\mathrm{pH}$ was measured and the initial $\mathrm{pH}\left(\mathrm{pH}_{0}\right)$ vs. the difference between the initial and final $\mathrm{pH}$ values $(\Delta \mathrm{pH})$ was plotted. The $\mathrm{pH}_{\mathrm{pzc}}$ was taken as the point where $\Delta \mathrm{pH}=0$.

\subsubsection{Morphology of the beads}


1 Surface morphology was characterized on a field-emission scanning electron microscope

2 (SEM). SEM was performed on a field effect JEOL JSM-6301F instrument equipped with an

3 EDS Oxford Inca Energy 300 SEM at an accelerating voltage of $15 \mathrm{kV}$.

\subsubsection{FTIR and XRD analysis}

Catalysts and virgin chitosan beads were characterized using a FTIR model spectrum 100 (PerkinElmer, USA) with a wavelength run of $4000-400 \mathrm{~cm}^{-1}$. For the same samples, XRD measurements were carried out using X'Pert PRO MPD X-ray diffractometer (PANalytical) with monochromatic Cu-K $\alpha$ radiation source $(\lambda=1,5418 \AA)$.

\subsection{Preparation of magnetic chitosan beads}

The chitosan used in the current work was extracted from shrimp shell waste according to the preparation method detailed by Islam et al [44]. Shrimp shells were collected from the central market of Tunis.

\subsubsection{One-step method for the preparation of magnetic chitosan gel beads (The in-situ method)}

The in-situ formation of magnetic particles in polymer matrix can be obtained by the alkaline co-precipitation of ferric and ferrous salts [45]. For the synthesis of magnetic chitosan gel beads, $\mathrm{Fe}^{3+}: \mathrm{Fe}^{2+}$ in the molar ratio 2:1 were added to $2 \%$ chitosan dissolved in acetic acid solution $1 \%$. The gel solution was mixed by constant stirring for 1 hour to obtain an orange homogeneous gel solution. Then, the mixture was dropped through a syringe into a hardening solution of sodium hydroxide $(1 \mathrm{M})$ to create spherical and uniform chitosan gel beads which have magnetic properties (Fig.2 and Fig.3). In contact with $\mathrm{NaOH}$ solution, the dark color of the beads indicates the in-situ precipitation of iron oxide. Nanoparticles of metal oxides, in particular, magnetite $\mathrm{Fe}_{3} \mathrm{O}_{4}$ and maghemite $\mathrm{Fe}_{2} \mathrm{O}_{3}$ are often synthesized by the alkaline coprecipitation of ferric and ferrous salts. [46].

The obtained particles were washed with deionized water for several times until $\mathrm{pH}$ reached a constant value $(\approx 6)$. Then, the prepared beads were dried at room temperature.

Figure 2

Figure 3 
2.4.2. Method 2: the mixing of pre-formed polymer and magnetic particles (The ex-situ method)

For comparison, magnetic chitosan beads $\mathrm{Fe}_{3} \mathrm{O}_{4}$-Cs was prepared by deposition of magnetite $\left(\mathrm{Fe}_{3} \mathrm{O}_{4}\right)$ at the surface of chitosan gel beads. Chitosan beads were prepared by the previously described method without the addition of iron. Thereafter, prepared particles were introduced into $1 \%$ magnetite suspension. The mixture was stirred for 12 hours using an incubator shaker (innova@ ${ }^{@}$ ).

\section{Results and discussion}

\subsection{Structural and textural characterization of the catalyst}

\subsubsection{Principle of in-situ preparation of magnetite nanoparticles in chitosan matrix}

The main advantage of the in-situ approach is the synthesis of the nanosized magnetite and the solidification of chitosan beads in the alkaline co-precipitation bath. This occurs in one step and can be described according to the following reaction:

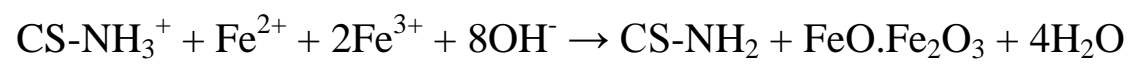

As explained by Wang [47], ferric and ferrous ions are chelated by amino groups of chitosan in the prepared mixture CS/iron salts gel solution. Then, in contact with hydroxide ions the chelated ferrous and ferric ions $\left[\left(\text { chitosan- } \mathrm{NH}_{2}\right)_{2}-\mathrm{Fe}^{2+}\right.$, $\left.\left(\text { chitosan- } \mathrm{NH}_{2}\right)_{2}-\mathrm{Fe}^{3+}\right]$ provide nucleation site for magnetite crystals. Thus, $\mathrm{Fe}_{3} \mathrm{O}_{4}$ and chitosan would be precipitated at the same time. The scheme of the in-situ preparation principle of magnetite in chitosan matrix is presented in Figure 4.

This way of preparation is more advantageous than that involving magnetite powder, since it allows a better homogenization of the solution and thus minimizes the loss of magnetic material during the preparation procedure [48]. The homogeneous distribution of metal oxide in the catalyst is due to the uniform distribution of amino groups in the chitosan matrix. Therefore, formed metal nanoparticles are strongly bound to chitosan by combination with a wide number of active sites of the polymer [49]. In fact, in the in-situ approach, the polymer is involved in the synthesis of metal oxide nanoparticles; it has therefore a positive impact on their stabilization and their isolation reduces the problem of aggregation. This can enhance the catalytic performance of prepared magnetic chitosan beads. To highlight the effect of iron concentration on the textural proprieties of the catalyst, the amount of iron added to chitosan gel solution (2\%) was varied from 5 to $15 \mathrm{mmoL}$ per $1 \mathrm{~g}$ of chitosan flakes. The obtained catalysts were characterized by SEM image, XRD and FTIR analysis. 


\subsubsection{Morphology and bead size measurements}

For the in-situ approach, the morphology of the beads surface and the core observed by SEM micrographs (Fig.5) after drying demonstrated that, for high concentrations of iron ( $\geq 10 \mathrm{mmoL}$ of iron/1g of CS) (Fig.5.a and Fig.5.b), beads have an elongated spherical form with a rather smooth surface. For a low concentration of iron $(=5 \mathrm{mmoL}$ of iron $/ 1 \mathrm{~g}$ of CS) (Fig.5.c), the bead loses its spherical shape and its surface became crumpled.

For these catalysts, wet beads had a spherical form. After drying, beads with a high amount of iron retained their spherical shape. In contrast, beads with a low amount of iron showed an empty pocket structure similar to that found by Xiaopeng Xiong et al who explained this result by the shrinkage of the particles by removal of the inside water during drying [50].

Besides, the difference between the surface of chitosan without and with the deposit of $\mathrm{Fe}_{3} \mathrm{O}_{4}$ nanoparticles was obvious in Fig 5.d and Fig 5.e respectively; magnetite particles are visible on the surface of $\mathrm{Fe}_{3} \mathrm{O}_{4}$-Cs beads prepared by the ex-situ approach.

\section{Figure 5}

The dried bead size was measured by laser diffractometry using (Mictotrac-S3500) considering the MIE and FRAUNHOFER theory (0.02 microns to 2800 microns). For all $\mathrm{Fe}_{3} \mathrm{O}_{4}$-Cs beads prepared via the in-situ approach, the diameter is still constant, and it is estimated to around $1.3 \mathrm{~mm}$ (Fig.3.d). Therefore, the size of beads is not affected by the amount of iron salts added initially to the chitosan gel matrix.

\subsubsection{Phase structure of the catalysts}

The presence of magnetite $\left(\mathrm{Fe}_{3} \mathrm{O}_{4}\right)$ phase was confirmed by XRD analysis of dried $\mathrm{CS} / \mathrm{Fe}_{3} \mathrm{O}_{4}$ beads (in situ synthesis) (Fig.6). The iron oxide phase was identified from the XRD patterns by the peak positions at $2 \Theta=30.4^{\circ}, 35.7^{\circ}, 43.5^{\circ}, 53.4^{\circ}, 57.4^{\circ}, 63.1^{\circ}$ and $73.0^{\circ}$, which can be attributed to the diffraction planes of (220), (311), (400), (422), (511), (440), (533), respectively, for the crystallized structure of the $\mathrm{Fe}_{3} \mathrm{O}_{4}$.

The mean size of the ferromagnetic particles, prepared in-situ in the beads was $10.2 \mathrm{~nm}$, as calculated by the Scherrer's equation (Eq.4).

$$
D=\frac{\mathrm{K} \times \lambda}{\beta \times \cos (\Theta)}
$$


1 Where D is the mean size of crystallites (nm), K is a constant related to crystallite shape, normally taken as $0.9, \lambda$ is the X-ray wavelength, $\beta$ is the full width at half the maximum (radians) of the $\mathrm{X}$-ray diffraction peak and $\theta$ is the Bragg angle (deg).

This finding is in agreement with the related literature [51]; the $\mathrm{Fe}_{3} \mathrm{O}_{4}$ crystals induced by the chitosan hydrogel should have a narrow size distribution and a small diameter due to the restriction of iron ions by the chelation effect that avoids the crystal growth of magnetite. It has been reported that $\mathrm{Fe}_{3} \mathrm{O}_{4}$ particles with size lower than $20 \mathrm{~nm}$ are superparamagnetic [46]. Therefore, it might be assumed that a part of the magnetite, formed in situ in the beads, was in a superparamagnetic state. It means that they are easily attracted by a magnetic field, but retain no residual magnetism at zero magnetic field [52]. The superparamagnetism is an important advantage which provided an additional stability of our catalyst and its dispersion after the application of an external magnetic field.

Furthermore, the size of $\mathrm{Fe}_{3} \mathrm{O}_{4}$ particles in the magnetic chitosan beads prepared by the exsitu method was estimated to be $45.3 \mathrm{~nm}$.

\section{Figure 6}

\subsubsection{FTIR analysis of the catalysts}

The deacetylation degree of the prepared chitosan (\% DD) was estimated at around $75 \%$ and it was evaluated using the equation 5 proposed by Brugnerotto et al [53].

$\% \mathrm{DD}=100-\left[\left[31.92 *\left(\mathrm{~A}_{1320} / \mathrm{A}_{1420}\right)\right]-12.20\right]$

Eq.5

Where $\mathrm{A}_{1320}$ and $\mathrm{A}_{1420}$ are the values of absorbance relative to baseline that occur in the FTIR spectrum of the extracted chitosan (Fig.7).

The binding of $\mathrm{Fe}_{3} \mathrm{O}_{4}$ to chitosan and the effect of the amount of iron in the chitosan matrix were also confirmed by FT-IR analysis. Figure 7 shows the FT-IR spectra of prepared catalysts and virgin chitosan powders. In the FT-IR spectra of chitosan, the characteristic bands of NH- and $\mathrm{OH}$ - stretching vibrations appeared at $3430 \mathrm{~cm}^{-1}$. The band at $1645 \mathrm{~cm}^{-1}$ was attributed to $\mathrm{NH}$ bending vibrations. The bands at $1150 \mathrm{~cm}^{-1}$ (-OH bending), $1072 \mathrm{~cm}^{-1}$ (C-O-C- stretching vibrations) and $1031 \mathrm{~cm}^{-1}$ (-OH bending) were due to the saccharide structure [48].

In the FT-IR spectra of the catalysts, a new band appeared in the low-frequency region (1000$500 \mathrm{~cm}^{-1}$ ) due to the iron oxide skeleton (-Fe-O- stretching vibration) which confirmed that the precipitation reactions carried out with chitosan produced a composite chitosan-Fe oxide 
nanoparticles [48, 54,55]. By increasing the amount of iron per mass of chitosan, the characteristic band of Fe-O became wide. Compared with the spectrum of chitosan, a slight shift and a significant decrease in the transmittance of the band at $3430 \mathrm{~cm}^{-1}$ occurred following iron addition. This indicated the occurrence of metal- $\mathrm{NH}_{2}$ bonds [56, 57].

\section{Figure 7}

\subsection{Degradation of chlordimeform by heterogeneous electro-Fenton process}

\subsubsection{Effect of the current intensity}

A key parameter in the electro-Fenton process is the applied current in two-electrode cells [58-60]. Zhimin Qiang et al.[60] investigated the optimal parameters such as the cathodic potential to improve the Faradic current efficiency of $\mathrm{H}_{2} \mathrm{O}_{2}$ production. They found that the optimal conditions for $\mathrm{H}_{2} \mathrm{O}_{2}$ generation are cathodic potential of $-0.5 \mathrm{~V}$ vs. saturated calomel electrode (SCE), with an oxygen mass flow rate of $8.2 \times 10^{-2} \mathrm{~mol} / \mathrm{min}$ in acidic conditions. In this context, an electrochemical study carried out previously, in our working conditions (data not shown), indicated that $-5 \mathrm{~mA}$ corresponded to an average current intensity obtained during electrolysis carried out at a constant potential of -0.5 V/EDS.

To confirm the effect of the current intensity on the electrochemical generation of $\mathrm{H}_{2} \mathrm{O}_{2}$ with the felt carbon cathode, electrolysis was performed in our experimental conditions $(30 \mathrm{~mL}$ of a $0.05 \mathrm{M} \mathrm{Na}_{2} \mathrm{SO}_{4}$ solution adjusted to an initial $\mathrm{pH}=3$ with concentrated $\mathrm{H}_{2} \mathrm{SO}_{4}$ ) by applying several cathodic current intensities. Figure 8 shows the effect of the applied current intensity on the amount of accumulated hydrogen peroxide during 4 hours of electrolysis. The hydrogen peroxide concentration was measured by titration with a solution of potassium permanganate $\mathrm{KMnO}_{4}$. As expected, the measured concentration of the oxidant depends on the applied intensity. Final solutions with $18.1 \pm 0.7,20.7 \pm 0.2,25.6 \pm 0.6$ and $28.2 \pm 0.5 \mathrm{mM}$ hydrogen peroxide were obtained, after 4 hours of electrolysis, at $-30,-20,-10$ and $-5 \mathrm{~mA}$, respectively. Thus, the maximum hydrogen peroxide concentration was achieved at an applied cathodic current of $-5 \mathrm{~mA}$.

Taking into account that the degradation of CDM occurs by the reaction with hydroxyl radicals ${ }^{\bullet} \mathrm{OH}$ produced by the activation of the electro-generated hydrogen peroxide on the actives sites of iron supported on chitosan beads, the rate of pollutant mineralization is directly affected by the amount of electro-generated hydrogen peroxide which is the precursor of this reaction. 
1 These results are confirmed by the study of the impact of the current intensity on the CDM

2 removal. To this purpose, various current intensities were applied, in the range of -5mA to -30 mA. Results in Fig.9.a show that changing the applied cathodic current did not lead to a significant increase in the kinetic of degradation of CDM. However, it is clear from Fig.9.b that the change of the applied cathodic current greatly influenced the rate of mineralization because the values of NPOC removal within 4 hours of electrolysis decreased from $51.2 \pm 4.5 \%$ to $14.9 \pm 0.5 \%$ for decreasing currents values from $-5 \mathrm{~mA}$ to $-30 \mathrm{~mA}$. For higher current intensity, the NPOC removal decreased to $29.5 \pm 0.2 \%$ for a cathodic current intensity equal to $-2.5 \mathrm{~mA}$. In the absence of catalyst, the yields of NPOC removal did not exceed $15.6 \pm 1.3 \%$ and $5.7 \pm 1.9 \%$ for $\mathrm{I}=-5 \mathrm{~mA}$ and $\mathrm{I}=-10 \mathrm{~mA}$, respectively.

From our study, the highest NPOC removal was obtained at an applied current equal to -5 $\mathrm{mA}$, which represents, as discussed above, the optimal applied current for the electrogeneration of oxidant species. An applied cathodic current of $-5 \mathrm{~mA}$ was therefore selected and considered thereafter.

To highlight the contribution of the adsorption process on the removal of the insecticide, the catalyst was introduced into CDM solutions in the absence of current. Results showed that the fraction of CDM adsorbed in magnetic chitosan beads did not exceed 3\%. This proves that there was no affinity between the target molecule and the catalyst. This result can be explained by the point of zero charge (pzc) value of the $\mathrm{Fe}_{3} \mathrm{O}_{4}$-Cs beads which is around $\mathrm{pH}=7$ (Table 1). Thus, the catalyst surface is positively charged in acidic media $(\mathrm{pH}<7)$, whereas it is negatively charged under alkaline conditions $(\mathrm{pH}>7)$. At $\mathrm{pH}=3$, the charge of catalyst surface is positive. However, the charge of CDM $(\mathrm{pKa}=3.85)$ is neutral. This accounts for the weak interaction between the pollutant and the catalyst as proved by the adsorption test.

\section{Figure 8}

\section{Figure 9}

\subsubsection{Effect of the amount of iron in chitosan beads}

The catalytic activity is influenced by the availability of active sites (iron) on the surface of the catalyst which react, as mentioned previously, with hydrogen peroxide in order to generate hydroxyl radicals [29].To highlight the effect of the iron content on the catalytic properties of magnetic chitosan beads, the amount of iron added initially to the chitosan matrix was varied from 5 to 15 mmol per 1 gram of polymer flakes. Iron analysis was carried out by atomic absorption spectroscopy to quantify the amount of metal/mass of catalyst for 
each sample. The corresponding results are shown in Table.1. It can be noted that for the higher iron content ( $>15 \mathrm{mmol}$ of iron/1 $\mathrm{g}$ of chitosan), the rigidity of the beads decreased; they could be easily broken by simple magnetic stirring.

Fig.10 shows the time-courses of CDM removal during the electro-Fenton reaction. It can be seen that the kinetics of pollutant removal increased with increasing iron concentration and total removal was observed within $60 \mathrm{~min}$ as shown in Fig.10.b. The removal of the pesticide was found to follow a pseudo-first order kinetic model with $\mathrm{k}=0.072 \mathrm{~min}^{-1}, 0.110 \mathrm{~min}^{-1}$ and $0.160 \mathrm{~min}^{-1}$ for $0.046 \mathrm{mmol}, 0.083 \mathrm{mmol}$ and $0.104 \mathrm{mmol}$ of iron per $15 \mathrm{mg}$ of catalyst, respectively. The mineralization yields (Table 2) also increased with the mass of iron, from $61.4 \pm 2.1 \%$ to $79.7 \pm 1.7 \%$, for amounts of iron per mass of chitosan increasing from 0.046 mmol to $0.104 \mathrm{mmol}$, after $6 \mathrm{~h}$ of treatment.

To better understand the effect of the amount of iron on the structural and textural properties of magnetic chitosan beads, XRD and FTIR analysis and SEM micrographs were done.

From the diffractogram XRD (Fig.6), it can be concluded that the catalytic activity increased for higher crystalline structure. However, the crystallinity is a necessary but not the only important factor affecting the catalytic performance. The activity of catalyst is also affected by surface area and the porosity, which could be related to the increase of the amount of active sites available for the reaction. Thus, the highest amount $(0.104 \mathrm{mmol})$ was selected as the optimal amount of iron supported on chitosan beads, ensuring a good stability of the catalyst and a high catalytic activity; it was therefore considered thereafter. As observed above, negligible involvement of pesticide adsorption on the chitosan beads, containing iron or not, was confirmed.

\section{Table 1}

Figure 10

\subsubsection{Effect of the catalyst dosage}

In heterogeneous systems, the catalyst dosage plays a crucial role since it controls the rate of hydroxyl radicals' production. Thus, it is one of the major parameters to be studied. For this purpose, several experiments were performed with 0.25 g. $\mathrm{L}^{-1}, 0.5$ g.L $\mathrm{L}^{-1}$ and 0.75 g. $\mathrm{L}^{-1}$ of catalyst. 
1 As can be seen when the catalyst dosage increased from 0.25 g. $\mathrm{L}^{-1}$ to 0.5 g. $\mathrm{L}^{-1}$, the percentage

2 of degradation of CDM increased within 30 min from $65.5 \pm 2.2 \%$ to $99.1 \pm 0.9 \%$ (Fig.11), and the rate of NPOC removal after 6 hours of treatment increased from $63.5 \pm 0.8 \%$ to $79.7 \pm 1.7 \%$ respectively (Table2), because increasing the accessibility of iron led to an increase of catalytic active sites. However, beyond 0.5 g. $\mathrm{L}^{-1}$ of catalyst, the CDM removal and the mineralization yields decreased to $82.6 \pm 4.2 \%$ (Fig.11) and 71.8 $\pm 1.3 \%$ (Table2), respectively. This can be explained by the reaction of hydroxyl radicals with the excess of active iron sites as shown in Eq.6.

$\mathrm{Fe}^{2+}+{ }^{\bullet} \mathrm{OH} \rightarrow \mathrm{Fe}^{3+}+\mathrm{OH}^{-}$

Otherwise, it has been reported that the increase of the catalyst dosage, may reduce the current intensity [28]. In fact, as commonly known, the mass of catalyst can greatly affect the mass transport in the medium which reduce the current intensity.

The degradation of CDM, with the change of catalyst concentration, followed a pseudo first order kinetic as shown in Fig.11.b, as found previously in Fig.10.b. The kinetic constants were found to be $0.042 \mathrm{~min}^{-1}, 0.160 \mathrm{~min}^{-1}$ and $0.057 \mathrm{~min}^{-1}$ for 0.25 g.L $\mathrm{L}^{-1}, 0.5$ g.L $\mathrm{L}^{-1}$ and 0.75 g. $L^{-1}$, respectively.

From the above results, 0.5 g. $\mathrm{L}^{-1}$ was the optimal catalyst amount and was therefore considered thereafter.

\section{Figure 11}

\subsubsection{Comparison of the different preparation methods of $\mathrm{Fe}_{3} \mathrm{O}_{4}-\mathrm{CS}$ beads}

Among the classical synthesis methods, detailed by White et al. [38] for the chemical preparation of supported metal nanoparticules on porous materials, two different methods were compared in the present study: The first was the synthesis in situ of the $\mathrm{Fe}_{3} \mathrm{O}_{4}$ on a polymer matrix by the co-precipitation method; for comparison, the second method was a simple deposition of $\mathrm{Fe}_{3} \mathrm{O}_{4}$ nanoparticles on pre-formed chitosan gel beads surface.

The $\mathrm{Fe}_{3} \mathrm{O}_{4}$-Cs beads prepared by the co-precipitation method were found to have a higher catalytic activity: it was observed $99.1 \pm 0.9 \%$ and $85.4 \pm 0.6 \%$ CDM removal within 30 min (Fig.12) and 79.7 $\pm 1.7 \%$ and 37.8 $\pm 2.3 \%$ mineralization after 6 hours (Table 2) of electrolysis by the methods 1 and 2, respectively. The first method allowed the incorporation of a considerable amount of magnetite in the beads $(0.1039 \pm 0.0014 \mathrm{mmol}$ of iron/ mass of 
catalyst) with higher homogeneous dispersion compared to the deposition method of

2 magnetite at the surface of chitosan beads. Indeed, the amount of iron deposited at the surface of $\mathrm{Fe}_{3} \mathrm{O}_{4}$-Cs beads prepared via the ex-situ approach was estimated to be $0.0422 \pm 0.0008$ $\mathrm{mmol} / \mathrm{mass}$ of catalyst.

Compared to the ex-situ method for the preparation of magnetic beads, the in-situ approach was simpler and ensured a spherical and uniform shape (Fig.5) and a good rigidity of the beads with high magnetic properties. Furthermore, it exhibited, as demonstrated previously, a high catalytic activity. For these reasons, the co-precipitation method of chitosan and magnetic particles was chosen for the preparation of magnetic chitosan beads.

Figure 12

\subsubsection{Comparison of the homogeneous and heterogeneous Fenton processes}

The degradation of CDM by the electro-Fenton process was studied with the same amount of supported and free iron. The heterogeneous electro-Fenton process was found to be slightly more efficient for the removal of CDM than the homogeneous process (Fig.13). The difference was clearly more pronounced upon examination of mineralization yields, $79.6 \pm 1.1 \%$ and $65.6 \pm 4.2 \%$ for the heterogeneous and homogeneous processes after $6 \mathrm{~h}$ of electrolysis, respectively (Table 2). This finding can be attributed to a precipitation of iron(III) in the homogeneous process which causes a reduction of the dissolved iron concentration [28]. Furthermore, homogeneous processes have some disadvantages, such as production of sludge with a high content in iron and iron deactivation by the formation of complexing agents [61].

\section{Figure 13}

\subsubsection{Effect of $\mathrm{pH}$}

The solution $\mathrm{pH}$ is an important control parameter for maintaining the effectiveness of the EF process. Several authors [20, 27, 62-66] have reported maximum efficiency in undivided cells with carbon-felt and gas diffusion (GDE) cathodes at $\mathrm{pH} 3.0$, which is close to $\mathrm{pH} 2.8$ where the maximum production of ${ }^{\bullet} \mathrm{OH}$ is expected from the Fenton's reaction. The $\mathrm{pH}$ was varied in the range of 2 to 7 and was found to be optimal around 3 with a total removal of CDM within 30 min. The $\mathrm{pH}$ was measured at the end of each test. No significant change was recorded between initial and final value of $\mathrm{pH}$. 
1 The low efficiency at lower $\mathrm{pH}(\mathrm{pH}=2)$ could be attributed to the stabilization of $\mathrm{H}_{2} \mathrm{O}_{2}$ which

2 can form oxonium ion by solvating a proton. In the form of oxonium ion, hydrogen peroxide becomes electrophilic, leading to the enhancement of its stability and presumably to reduce substantial reactivity with ferrous ion as follows [67]:

$$
\mathrm{H}_{2} \mathrm{O}_{2}+\mathrm{H}^{+} \rightarrow \mathrm{H}_{3} \mathrm{O}_{2}^{+}
$$

It is remarkable from the Figure.14 that a significant degradation of CDM occurred at neutral $\mathrm{pH}(95.6 \pm 1.7 \%$ within $60 \mathrm{~min})$. However, only $32.7 \pm 2.3 \%$ of NPOC was removed after 6 hours of treatment, while it was $79.7 \pm 1.7 \%$ at $\mathrm{pH}=3$ (Table.2).

\section{Figure 14}

\subsubsection{Analysis of the degradation products of chlordimeform}

In order to elucidate a plausible reaction pathway of CDM with hydroxyl radicals generated by the heterogeneous Electro-Fenton process, a LC-MS/MS analysis was conducted to follow the gradual disappearance of the insecticide molecule as well as the formation and the disappearance of the intermediate compounds during four hours of treatment (Figure.15). The corresponding experiment was conducted in our optimal conditions. The identification was based on mass fragmentation values and by comparing the mass spectra to a database. The main compounds generated during the electro-Fenton treatment are described in Table3. The evolution of the intermediate products formed during electrolysis is shown in Fig.16. Degradation products of CDM were named $\mathrm{CDM}_{1 \ldots 3}$.

The oxidation of these derivatives with the electro-Fenton process led to the formation of short chain carboxylic acids which are the last by-products before mineralization; acetic acid (tr =3.35 min), formic acid ( $\operatorname{tr}=4.02 \mathrm{~min}$ ), succinic acid ( $\operatorname{tr}=15.23 \mathrm{~min}$ ) and oxalic acid (tr= $22.14 \mathrm{~min}$ ) were the main acids identified by ion chromatography in the final stage of CDM degradation; their retention times were compared with standard compounds. Time-courses of the carboxylic acid concentrations during treatment are given in Fig.17. The fluctuation of acetic acid concentration can be explained by the high affinity in water between chitosan and this acid as reported by Shamov et al [68].

The anions analysis by ion chromatography shows that the mineralization of CDM was accompanied by the conversion of its by-products into inorganic salts (data not shown). The CDM contains an atom of chlorine and two atoms of nitrogen. Therefore, the detection of inorganic salts such as chloride $\mathrm{Cl}^{-}$and nitrates $\mathrm{NO}_{3}{ }^{-}$was expected. However no nitrite $\mathrm{NO}_{2}{ }^{-}$ 
ions were produced. $25 \%$ of the expected amount of chloride ions from the target molecule

2 was detected after 6 hours of electrolysis. Nevertheless, a negligible amount of $\mathrm{NO}_{3}{ }^{-}$was

3 quantified during the electro-Fenton treatment. This could be explained by the nitrogen transformation into ammonium ions $\mathrm{NH}_{4}{ }^{+}$. For this reason, an essay was conducted in our optimal experimental conditions for the removal of CDM to quantify the amount of ammonium ions during treatment. The determination of the $\mathrm{NH}_{4}{ }^{+}$amount was performed by the Nessler spectrophotometric method. Results showed that after 6 hours of electrolysis, the totality of the nitrogen present in the target molecule was transformed to ammonium ions.

The mechanism for CDM degradation by hydroxyl radical in water has not been yet discussed in the available literature. However, Shengmin Sun et al [69], have studied this reaction in the atmosphere and they proposed several reaction channels including possible reactions initiated by hydroxyl radicals on the side chain and the benzene ring. Therefore, in Fig.18 two plausible mineralization sequences are proposed for CDM removal during the electro-Fenton process on the basis of the identified intermediates including the two possibilities of reaction of hydroxyl radicals: one on the aromatic ring (mechanism I) and the other on the side chain (mechanism II). A thorough theoretical investigation [69] demonstrated that the reaction of the carbon-nitrogen double bond is the major channel, while the abstraction reaction from the benzene ring of CDM is the least competitive method.

In fact, the main proposed reaction was the electrophilic addition of a hydroxyl radical on the side chain (mechanism II) leading to the formation of chlortoluron. In a second step the removal of chloride atom would lead to the production of a substituted urea (1,1-dimethyl-3(2-methylphenyl)urea). The next proposed step was the elimination of the $\mathrm{C}_{2} \mathrm{H}_{6} \mathrm{~N}$ molecule, which would lead to the production of a substituted alcohol ([(1methylphenyl)amino]methanol). This is the final detected by-product prior to the ringopening and the formation of short chain carboxylic acids.

\section{Figure.15}

Table.3

Figure 16

Figure 17

Figure 18 


\subsubsection{Reusability of the catalyst}

One of the most important advantages of heterogeneous catalysis is the reusability of the catalyst. To evaluate the stability of the catalytic activity of $\mathrm{Fe}_{3} \mathrm{O}_{4}-\mathrm{Cs}$ beads, the same catalyst was used successively four times. As can be seen, the catalyst can be reused four times without loss of its catalytic performance (Fig.19). After four times of catalyst usage, only $5.4 \%$ decrease of the mineralization yield was found. From these, $\mathrm{Fe}_{3} \mathrm{O}_{4}$-CS beads were found to be a stable and reusable catalyst in the heterogeneous electro-Fenton process. The quantitative results of the amount of leached iron showed a zero iron concentration after 24 hours of electrolysis time using the same catalyst. The negligible leaching of iron (inferior to the detection limit of the analysis technique estimated to $3.1 \mu \mathrm{mol} . \mathrm{L}^{-1}$ ) is due to the complex formation between amino groups of chitosan and iron as described previously. This is why the contribution of the leached iron in our heterogeneous system can be excluded and it can be affirmed that active catalytic sites are located on $\mathrm{Fe}_{3} \mathrm{O}_{4}$-Cs beads.

Furthermore, the molar ratio $\mathrm{Fe}^{2+} / \mathrm{Fe}^{3+}$ is one of the most important operating factors that influence the characteristics of $\mathrm{Fe}_{3} \mathrm{O}_{4}$ nanoparticles, and it can affect the catalytic performance of our catalyst [70-72]. For this reason, the evolution of the molar ratio $\mathrm{Fe}^{2+} / \mathrm{Fe}^{3+}$ was controlled during the preparation of $\mathrm{Fe}_{3} \mathrm{O}_{4}$-Cs beads and during the electrolysis assays. The experimental $\mathrm{Fe}^{2+} / \mathrm{Fe}^{3+}$ molar ratio being of the order of $0.517 \pm 0.028,0.481 \pm 0.001$ and $0.512 \pm 0.015$ in $\mathrm{CS} /$ iron salts gel solution (before the synthesis of $\mathrm{Fe}_{3} \mathrm{O}_{4}$ ) and in wet and dry $\mathrm{Fe}_{3} \mathrm{O}_{4}$-Cs beads (after the synthesis of $\mathrm{Fe}_{3} \mathrm{O}_{4}$ ) samples respectively (Table 4), namely close to the theoretical ratio of 0.5 , proves that the synthesized magnetite product is pure enough [73]. During electrolysis, the molar ratio $\mathrm{Fe}^{2+} / \mathrm{Fe}^{3+}$ in $\mathrm{Fe}_{3} \mathrm{O}_{4}$-Cs beads slightly decreased from initial value estimated to be $0.512 \pm 0.015$ to $0.422 \pm 0.088$ after 24 hours of electrolysis, with a negligible decrease of its catalytic performance as mentioned previously. This can be explained by the instability of magnetite under oxidizing conditions $\left(\mathrm{O}_{2}, \mathrm{H}_{2} \mathrm{O}_{2}\right)$ where it is slowly oxidized to maghemite $\left(\gamma-\mathrm{Fe}_{2} \mathrm{O}_{3}\right)$ which has the same spinal structure but contains only $\mathrm{Fe}(\mathrm{III})[72]$.

\section{Conclusion}


1 Magnetic chitosan beads $\left(\mathrm{Fe}_{3} \mathrm{O}_{4}\right.$-Cs) were prepared in one step by a simple co-precepitation method. $\mathrm{Fe}_{3} \mathrm{O}_{4}$-Cs beads exhibited a catalytic performance for the degradation of CDM by an EF process with a high magnetic recovery. Our heterogeneous $\mathrm{Fe}_{3} \mathrm{O}_{4}$-Cs-EF system showed a higher performances compared to the conventional EF process using the same amount of iron. The effect of the amount of iron in chitosan beads was investigated. The optimal content was found to be $0.104 \pm 0.001 \mathrm{mmol}$; complete CDM removal was observed within $30 \mathrm{~min}$ at an initial $\mathrm{pH}$ of 3.0, a cathodic current intensity of $-5 \mathrm{~mA}$ and in the presence of 0.5 g. $\mathrm{L}^{-1}$ catalyst amount. In terms of organic carbon removal, about $80 \%$ mineralization yield was reached in the optimal conditions after $6 \mathrm{~h}$ of heterogeneous electro-Fenton treatment time. A kinetic analysis showed that the removal of $\mathrm{CDM}$ by $\mathrm{Fe}_{3} \mathrm{O}_{4}$-Cs beads followed a first-order kinetic model $\left(\mathrm{kapp}=0.160 \mathrm{~min}^{-1}\right)$. The intermediate by-products including short-chain carboxylic acids were identified and their evolution during the EF treatment was followed leading to the proposal of a degradation pathway for chlordimeform via hydroxyl radicals.

The recyclability of the catalyst was shown since it can be reused at least four times with a good catalytic performance. The main advantage which provides the stability of our catalyst is the combination between amino groups of chitosan and iron in the structure of $\mathrm{Fe}_{3} \mathrm{O}_{4}$-Cs that minimize the possibility of iron leaching and inhibits the aggregation of $\mathrm{Fe}_{3} \mathrm{O}_{4}$ nanoparticles which display a superparamagnetic property $\left(\mathrm{Fe}_{3} \mathrm{O}_{4} \mathrm{size}=10.2 \mathrm{~nm}\right)$, giving to our catalyst an additional stability limiting its loss of dispersibility in the absence of magnetic field. Furthermore, $\mathrm{Fe}_{3} \mathrm{O}_{4}$-Cs offers many advantages: low cost and toxicity, availability and environmentally friendly potential which make this catalyst a good candidate for industrial application in the field of water treatment.

\section{Acknowledgement}

This research was supported by Tunisian Ministry of Higher Education and Scientific Research. The corresponding author is grateful to Wafa Najar from the National Center for Research in Materials Sciences (CNRSM, Tunisia) for the FTIR and XRD analysis.

\section{References}

[1] W. Zhang, F. Jiang, J. Ou, Global pesticide consumption and pollution: with China as a focus, Proceedings of the International Academy of Ecology and Environmental Sciences, 1 (2011) 125.

[2] D. Pimentel, Environmental and Economic Costs of the Application of Pesticides Primarily in the United States, in: R. Peshin, A.K. Dhawan (Eds.) Integrated Pest 
Management: Innovation-Development Process: Volume 1, Springer Netherlands, Dordrecht, 2009, pp. 89-111.

[3] J.A. Skinner, K.A. Lewis, K.S. Bardon, P. Tucker, J.A. Catt, B.J. Chambers, An Overview of the Environmental Impact of Agriculture in the U.K, Journal of Environmental Management, 50 (1997) 111-128.

[4] M. Margni, D. Rossier, P. Crettaz, O. Jolliet, Life cycle impact assessment of pesticides on human health and ecosystems, Agriculture, Ecosystems \& Environment, 93 (2002) 379392.

[5] R. McKinlay, J.A. Plant, J.N.B. Bell, N. Voulvoulis, Endocrine disrupting pesticides: Implications for risk assessment, Environment International, 34 (2008) 168-183.

[6] O. Osano, W. Admiraal, H.J.C. Klamer, D. Pastor, E.A.J. Bleeker, Comparative toxic and genotoxic effects of chloroacetanilides, formamidines and their degradation products on Vibrio fischeri and Chironomus riparius, Environmental Pollution, 119 (2002) 195-202. [7] L.G. Costa, Chlordimeform A2 - Wexler, Philip, Encyclopedia of Toxicology (Third Edition), Academic Press, Oxford, 2014, pp. 849-850.

[8] A.E. Lund, G.K.W. Yim, D.L. Shankland, The Cardiovascular Toxicity of Chlordimeform: A Local Anesthetic-Like Action, in: D.L. Shankland, R.M. Hollingworth, T. Smyth (Eds.) Pesticide and Venom Neurotoxicity, Springer US, Boston, MA, 1978, pp. 171177.

[9] W.K. Boyes, R.S. Dyer, Chlordimeform produces profound, selective, and transient changes in visual evoked potentials of hooded rats, Experimental neurology, 86 (1984) 434447.

[10] W.D. Thomas, G.K. Craig, N.H. Stacey, Effects of chlordimeform and its metabolite 4chloro-o-toluidine on rat splenic T, B and tumoricidal effector cells, Immunopharmacology, 19 (1990) 79-86.

[11] C.C. Davis, Environmental concerns about pesticide use in Philippine agriculture, Science of The Total Environment, 134 (1993) 293-306.

[12] R.E. Galt, Beyond the circle of poison: Significant shifts in the global pesticide complex, 1976-2008, Global Environmental Change, 18 (2008) 786-799.

[13] N. Wang, L. Shi, D. Kong, D. Cai, Y. Cao, Y. Liu, G. Pang, R. Yu, Accumulation levels and characteristics of some pesticides in human adipose tissue samples from Southeast China, Chemosphere, 84 (2011) 964-971.

[14] X. Yang, J. Luo, Y. Duan, S. Li, C. Liu, Simultaneous analysis of multiple pesticide residues in minor fruits by ultrahigh-performance liquid chromatography/hybrid quadrupole time-of-fight mass spectrometry, Food Chemistry, 241 (2018) 188-198.

[15] E. Korta, A. Bakkali, L.A. Berrueta, B. Gallo, F. Vicente, V. Kilchenmann, S. Bogdanov, Study of acaricide stability in honey. Characterization of amitraz degradation products in honey and beeswax, Journal of agricultural and food chemistry, 49 (2001) 5835-5842.

[16] X. Yi, L. Han, H. Yang, X. Fan, J. Zhu, D. Guo, [Determination of chlordimeform and its metabolite residues in honey using liquid chromatography-tandem mass spectrometry], Se $\mathrm{pu}=$ Chinese journal of chromatography, 28 (2010) 649-653.

[17] C. MAQUEDA, E. MORILLO, J.L. PÉREZ RODRÍGUEZ, A. JUSTO, ADSORPTION OF CHLORDIMEFORM BY HUMIC SUBSTANCES FROM DIFFERENT SOILS, Soil Science, 150 (1990) 431-437.

[18] A. Babuponnusami, K. Muthukumar, A review on Fenton and improvements to the Fenton process for wastewater treatment, Journal of Environmental Chemical Engineering, 2 (2014) 557-572.

[19] E. Neyens, J. Baeyens, A review of classic Fenton's peroxidation as an advanced oxidation technique, Journal of Hazardous Materials, 98 (2003) 33-50. 
[20] C. Annabi, F. Fourcade, I. Soutrel, F. Geneste, D. Floner, N. Bellakhal, A. Amrane, Degradation of enoxacin antibiotic by the electro-Fenton process: Optimization, biodegradability improvement and degradation mechanism, Journal of Environmental Management, 165 (2016) 96-105.

5 [21] D. Mansour, F. Fourcade, I. Soutrel, D. Hauchard, N. Bellakhal, A. Amrane, Relevance

6 of a combined process coupling electro-Fenton and biological treatment for the remediation of

7 sulfamethazine solutions - Application to an industrial pharmaceutical effluent, Comptes

8 Rendus Chimie, 18 (2015) 39-44.

9 [22] L. Ma, M. Zhou, G. Ren, W. Yang, L. Liang, A highly energy-efficient flow-through electro-Fenton process for organic pollutants degradation, Electrochimica Acta, 200 (2016) 222-230.

[23] H. Roth, Y. Gendel, P. Buzatu, O. David, M. Wessling, Tubular carbon nanotube-based gas diffusion electrode removes persistent organic pollutants by a cyclic adsorption - ElectroFenton process, Journal of Hazardous Materials, 307 (2016) 1-6. [24] K. Cruz-González, O. Torres-López, A. García-León, J.L. Guzmán-Mar, L.H. Reyes, A. Hernández-Ramírez, J.M. Peralta-Hernández, Determination of optimum operating parameters for Acid Yellow 36 decolorization by electro-Fenton process using BDD cathode, Chemical Engineering Journal, 160 (2010) 199-206. of Hazardous Materials, 152 (2008) 601-606.

[26] A. Wang, J. Qu, J. Ru, H. Liu, J. Ge, Mineralization of an azo dye Acid Red 14 by electro-Fenton's reagent using an activated carbon fiber cathode, Dyes and Pigments, 65 (2005) 227-233.

[27] S.B. Hammouda, F. Fourcade, A. Assadi, I. Soutrel, N. adhoum, A. Amrane, L. Monser, Effective heterogeneous electro-Fenton process for the degradation of a malodorous compound, indole, using iron loaded alginate beads as a reusable catalyst, Applied Catalysis B: Environmental, 182 (2016) 47-58.

[28] O. Iglesias, J. Gómez, M. Pazos, M.Á. Sanromán, Electro-Fenton oxidation of imidacloprid by Fe alginate gel beads, Applied Catalysis B: Environmental, 144 (2014) 416424.

[29] E.G. Garrido-Ramírez, J.F. Marco, N. Escalona, M.S. Ureta-Zañartu, Preparation and characterization of bimetallic $\mathrm{Fe}-\mathrm{Cu}$ allophane nanoclays and their activity in the phenol oxidation by heterogeneous electro-Fenton reaction, Microporous and Mesoporous Materials, 225 (2016) 303-311.

[30] C. Zhang, M. Zhou, X. Yu, L. Ma, F. Yu, Modified iron-carbon as heterogeneous electro-Fenton catalyst for organic pollutant degradation in near neutral $\mathrm{pH}$ condition: Characterization, degradation activity and stability, Electrochimica Acta, 160 (2015) 254-262. [31] Z. Dong, X. Le, X. Li, W. Zhang, C. Dong, J. Ma, Silver nanoparticles immobilized on fibrous nano-silica as highly efficient and recyclable heterogeneous catalyst for reduction of 4-nitrophenol and 2-nitroaniline, Applied Catalysis B: Environmental, 158-159 (2014) 129135.

[32] S. Xing, Z. Zhou, Z. Ma, Y. Wu, Characterization and reactivity of Fe3O4/FeMnOx core/shell nanoparticles for methylene blue discoloration with H2O2, Applied Catalysis B: Environmental, 107 (2011) 386-392.

[33] L. Hou, L. Wang, S. Royer, H. Zhang, Ultrasound-assisted heterogeneous Fenton-like degradation of tetracycline over a magnetite catalyst, Journal of Hazardous Materials, 302 (2016) 458-467. 
[34] M. Minella, G. Marchetti, E. De Laurentiis, M. Malandrino, V. Maurino, C. Minero, D. Vione, K. Hanna, Photo-Fenton oxidation of phenol with magnetite as iron source, Applied Catalysis B: Environmental, 154-155 (2014) 102-109.

[35] M. Mascolo, Y. Pei, T. Ring, Room Temperature Co-Precipitation Synthesis of Magnetite Nanoparticles in a Large pH Window with Different Bases, Materials, 6 (2013) 5549.

[36] B. Hou, H. Han, S. Jia, H. Zhuang, P. Xu, D. Wang, Heterogeneous electro-Fenton oxidation of catechol catalyzed by nano-Fe3O4: kinetics with the Fermi's equation, Journal of the Taiwan Institute of Chemical Engineers, 56 (2015) 138-147.

[37] A. Kaushik, P.R. Solanki, A.A. Ansari, G. Sumana, S. Ahmad, B.D. Malhotra, Iron oxide-chitosan nanobiocomposite for urea sensor, Sensors and Actuators B: Chemical, 138 (2009) 572-580.

[38] R.J. White, R. Luque, V.L. Budarin, J.H. Clark, D.J. Macquarrie, Supported metal nanoparticles on porous materials. Methods and applications, Chemical Society Reviews, 38 (2009) 481-494.

[39] Y. Lee, W. Lee, Degradation of trichloroethylene by Fe(II) chelated with cross-linked chitosan in a modified Fenton reaction, J Hazard Mater, 178 (2010) 187-193.

[40] E. Guibal, Heterogeneous catalysis on chitosan-based materials: a review, Progress in Polymer Science, 30 (2005) 71-109.

[41] S. Sarkar, E. Guibal, F. Quignard, A.K. SenGupta, Polymer-supported metals and metal oxide nanoparticles: synthesis, characterization, and applications, Journal of Nanoparticle Research, 14 (2012) 1-24.

[42] A. Elmagirbi, H. Sulistyarti, A. Atikah, Study of Ascorbic Acid as Iron(III) Reducing Agent for Spectrophotometric Iron Speciation, 2012.

[43] A. M Cardenas-Peña, J. Ibanez, R. Vasquez-Medrano, Determination of the Point of Zero Charge for Electrocoagulation Precipitates from an Iron Anode, 2012.

[44] M. Islam, S. Md. Masum, M. Rahman, M. Ashraful Islam, A. A. Shaikh, S.K. Roy, Preparation of Chitosan from Shrimp Shell and Investigation of Its Properties, 2011.

[45] V.C. R. Massart, Synthese en milieu alcaline de magnetite colloidale J Chim Phys 84 (1987) 967.

[46] M.A.M. Gijs, Magnetic bead handling on-chip: new opportunities for analytical applications, Microfluidics and Nanofluidics, 1 (2004) 22-40.

[47] Y. Wang, B. Li, Y. Zhou, D. Jia, In Situ Mineralization of Magnetite Nanoparticles in Chitosan Hydrogel, Nanoscale research letters, 4 (2009) 1041-1046.

[48] O. Stoilova, H. Penchev, T. Ruskov, I. Spirov, N. Manolova, I. Rashkov, One-pot preparation of magnetic chitosan beads, Bulgarian chemical communications, 40 (2008) 491497.

[49] M. Lee, B.-Y. Chen, W. Den, Chitosan as a Natural Polymer for Heterogeneous Catalysts Support: A Short Review on Its Applications, Applied Sciences, 5 (2015) 1272.

[50] X. Xiong, Y. Wang, W. Zou, J. Duan, Y. Chen, Preparation and Characterization of Magnetic Chitosan Microcapsules, Journal of Chemistry, 2013 (2013) 8.

[51] Y. Wang, B. Li, Y. Zhou, D. Jia, Chitosan-induced synthesis of magnetite nanoparticles via iron ions assembly, Polymers for Advanced Technologies, 19 (2008) 1256-1261.

[52] Wahajuddin, S. Arora, Superparamagnetic iron oxide nanoparticles: magnetic nanoplatforms as drug carriers, International Journal of Nanomedicine, 7 (2012) 3445-3471. [53] J. Brugnerotto, J. Lizardi, F.M. Goycoolea, W. Argüelles-Monal, J. Desbrières, M. Rinaudo, An infrared investigation in relation with chitin and chitosan characterization, Polymer, 42 (2001) 3569-3580.

[54] L. Zhang, X. Zhu, S. Zheng, H. Sun, Photochemical preparation of magnetic chitosan beads for immobilization of pullulanase, Biochemical Engineering Journal, 46 (2009) 83-87. 
[55] H.L. Ma, X.R. Qi, Y. Maitani, T. Nagai, Preparation and characterization of superparamagnetic iron oxide nanoparticles stabilized by alginate, International journal of pharmaceutics, 333 (2007) 177-186.

[56] Z. Abdeen, S.G. Mohammad, M.S. Mahmoud, Adsorption of Mn (II) ion on polyvinyl alcohol/chitosan dry blending from aqueous solution, Environmental Nanotechnology, Monitoring \& Management, 3 (2015) 1-9.

[57] L. Jin, R. Bai, Mechanisms of Lead Adsorption on Chitosan/PVA Hydrogel Beads, Langmuir, 18 (2002) 9765-9770.

[58] J. Paramo-Vargas, A.M.E. Camargo, S. Gutierrez-Granados, L.A. Godinez, J.M. PeraltaHernandez, Applying electro-Fenton process as an alternative to a slaughterhouse effluent treatment, Journal of Electroanalytical Chemistry, 754 (2015) 80-86.

[59] G. Santana-Martinez, G. Roa-Morales, E.M. del Campo, R. Romero, B.A. FrontanaUribe, R. Natividad, Electro-Fenton and Electro-Fenton-like with in situ electrogeneration of H2O2 and catalyst applied to 4-chlorophenol mineralization, Electrochimica Acta, 195 (2016) 246-256.

[60] Z. Qiang, J.-H. Chang, C.-P. Huang, Electrochemical generation of hydrogen peroxide from dissolved oxygen in acidic solutions, Water Research, 36 (2002) 85-94.

[61] M. Blanco, A. Martinez, A. Marcaide, E. Aranzabe, A. Aranzabe, Heterogeneous Fenton Catalyst for the Efficient Removal of Azo Dyes in Water, 2014.

[62] F. Sopaj, N. Oturan, J. Pinson, F. Podvorica, M.A. Oturan, Effect of the anode materials on the efficiency of the electro-Fenton process for the mineralization of the antibiotic sulfamethazine, Applied Catalysis B: Environmental, 199 (2016) 331-341.

[63] D. Gümüș, F. Akbal, COMPARISON OF FENTON AND ELECTRO-FENTON PROCESSES FOR OXIDATION OF PHENOL, Process Safety and Environmental Protection.

[64] H. Lin, N. Oturan, J. Wu, H. Zhang, M.A. Oturan, Cold incineration of sucralose in aqueous solution by electro-Fenton process, Separation and Purification Technology, 173 (2017) 218-225.

[65] H. Lan, W. He, A. Wang, R. Liu, H. Liu, J. Qu, C.P. Huang, An activated carbon fiber cathode for the degradation of glyphosate in aqueous solutions by the Electro-Fenton mode: Optimal operational conditions and the deposition of iron on cathode on electrode reusability, Water Research, 105 (2016) 575-582.

[66] M. Panizza, G. Cerisola, Electro-Fenton degradation of synthetic dyes, Water Research, 43 (2009) 339-344.

[67] H. Hassan, B. Hameed, Fenton-like Oxidation of Acid Red 1 Solutions UsingHeterogeneous Catalyst Based on Ball Clay, International Journal of Environmental Science and Development, 2 (2011) 218.

[68] M.V. Shamov, S. Bratskaya, V. Avramenko, Interaction of Carboxylic Acids with Chitosan: Effect of pK and Hydrocarbon Chain Length, 2002.

[69] S. Sun, K. Zhang, Y. Lu, H. Zhang, Theoretical study on the reaction mechanism of chlordimeform with OH radicals, Journal of Molecular Modeling, 20 (2014) 1-10.

[70] S. Laurent, D. Forge, M. Port, A. Roch, C. Robic, L. Vander Elst, R.N. Muller, Magnetic iron oxide nanoparticles: synthesis, stabilization, vectorization, physicochemical characterizations, and biological applications, Chemical reviews, 108 (2008) 2064-2110.

[71] W. Jiang, K.-L. Lai, H. Hu, X.-B. Zeng, F. Lan, K.-X. Liu, Y. wu, Z.-W. Gu, The effect of $[\mathrm{Fe} 3+] /[\mathrm{Fe} 2+]$ molar ratio and iron salts concentration on the properties of superparamagnetic iron oxide nanoparticles in the water/ethanol/toluene system, 2011.

[72] K. Rusevova, F.-D. Kopinke, A. Georgi, Nano-sized magnetic iron oxides as catalysts for heterogeneous Fenton-like reactions-Influence of $\mathrm{Fe}(\mathrm{II}) / \mathrm{Fe}(\mathrm{III})$ ratio on catalytic performance, Journal of Hazardous Materials, 241-242 (2012) 433-440. 
1 [73] M.C. Mascolo, Y. Pei, T.A. Ring, Room Temperature Co-Precipitation Synthesis of

2 Magnetite Nanoparticles in a Large pH Window with Different Bases, Materials, 6 (2013)

3 5549-5567.

\section{$4 \quad$ List of figures}

$5 \quad$ In print, figures should be colored.

6

7

8

9

10

11

12<smiles>Cc1cc(Cl)ccc1/N=C/N(C)C</smiles>

Fig.1. Chlordimeform molecule.
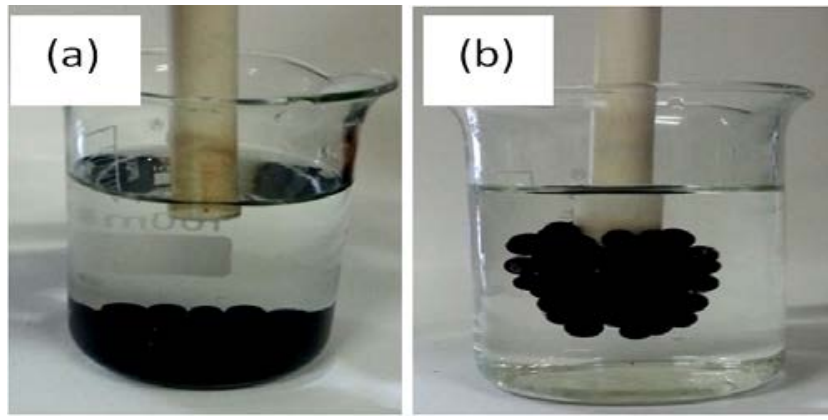

Fig.2. Superparamagnetic behaviors of the magnetic gel beads: (a) without external magnetic field and (b) its magnetic properties when an external field was applied.

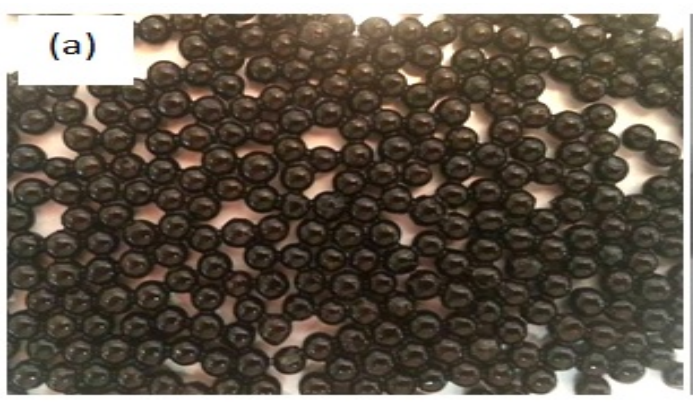

\section{(b)}
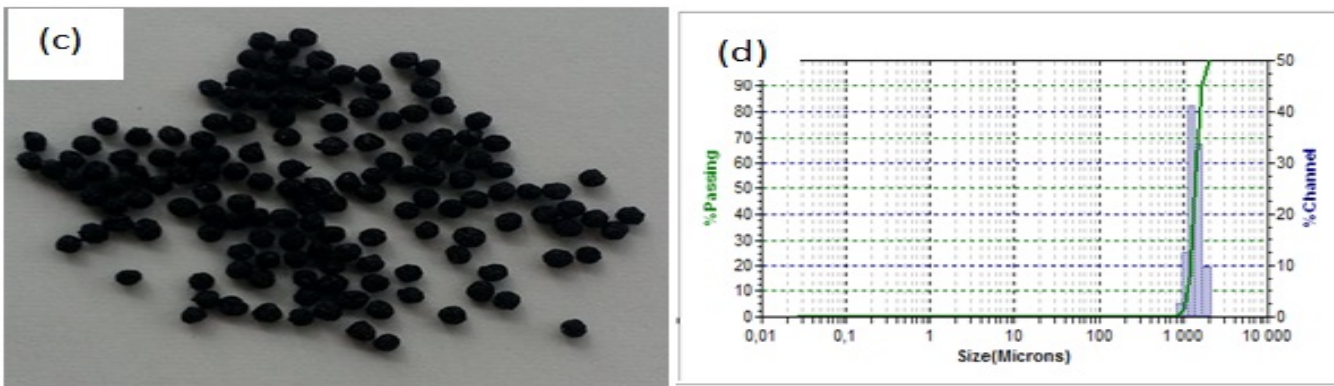
Fig.3. Digital photographs of the magnetic chitosan beads prepared by the approach in-situ:

(a) wet beads; (b) dry beads with external magnetic field; (c) dry beads without external magnetic field (d) The schematic of laser diffractometry measurement for $\mathrm{Fe}_{3} \mathrm{O}_{4}$-Cs beads.

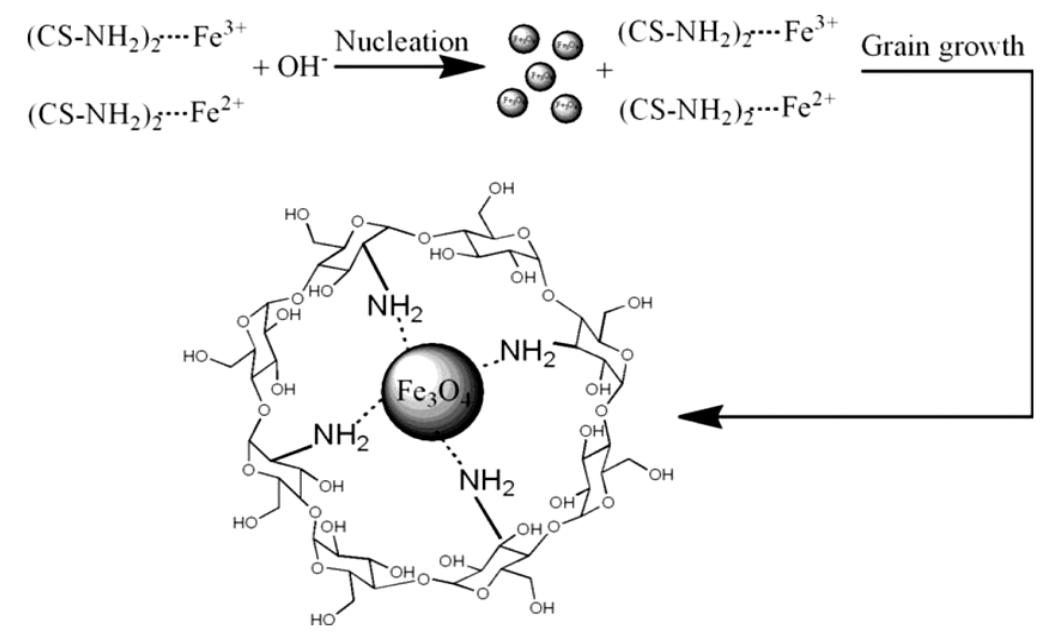

Fig.4. Principle of in-situ mineralization of magnetite nanoparticles in chitosan hydrogel [37].
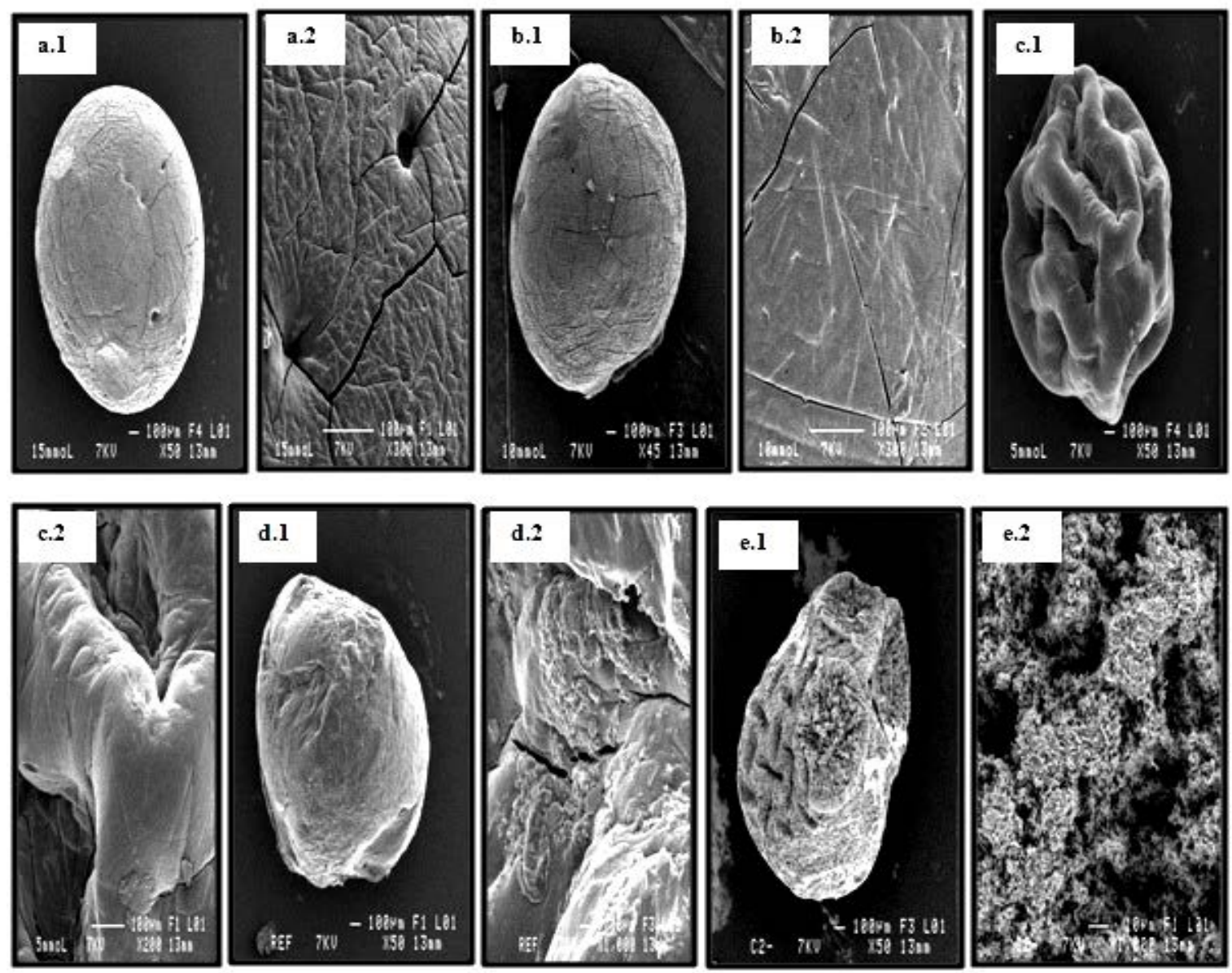


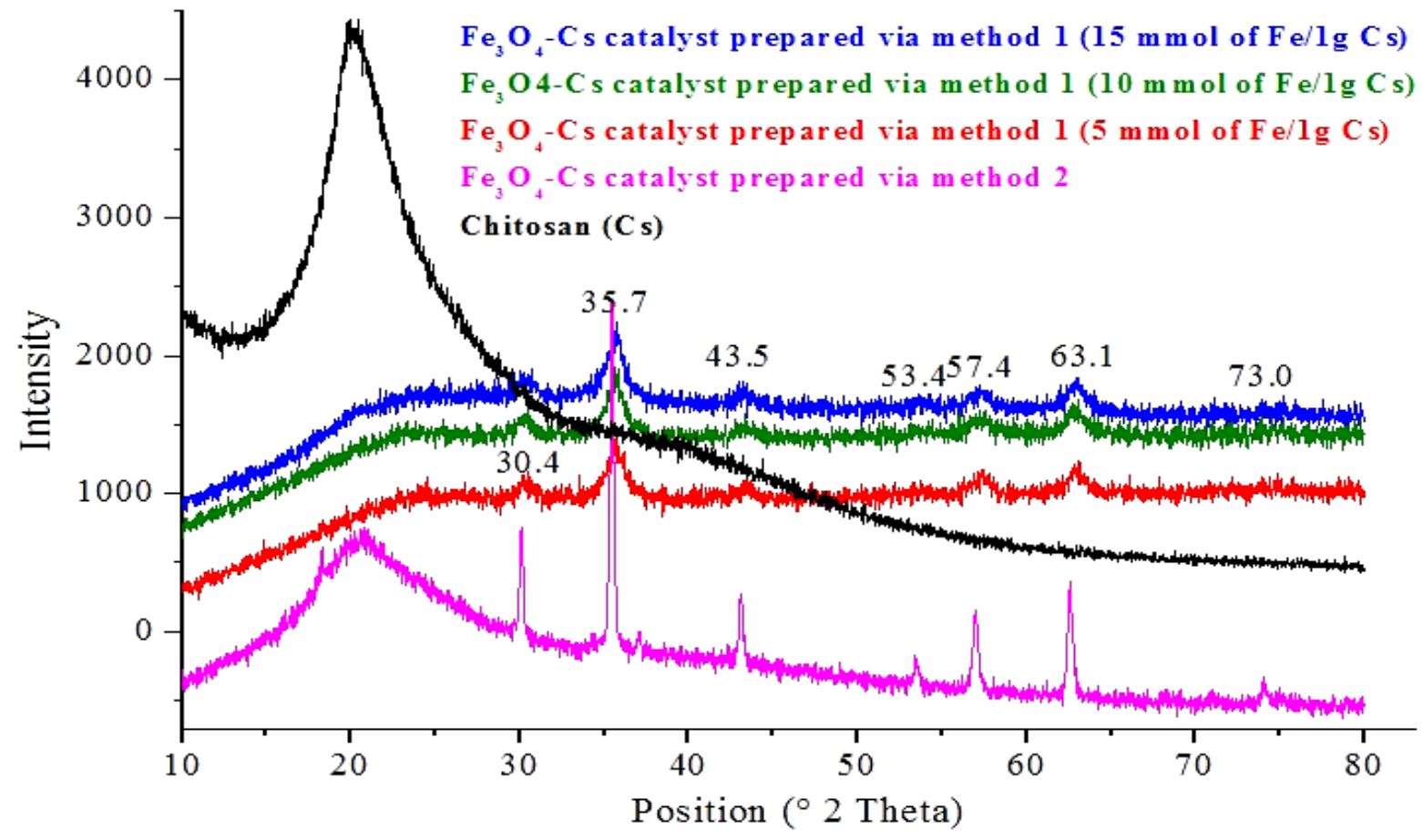

Fig.6. X-ray powder diffractograms of the prepared magnetic chitosan beads. 


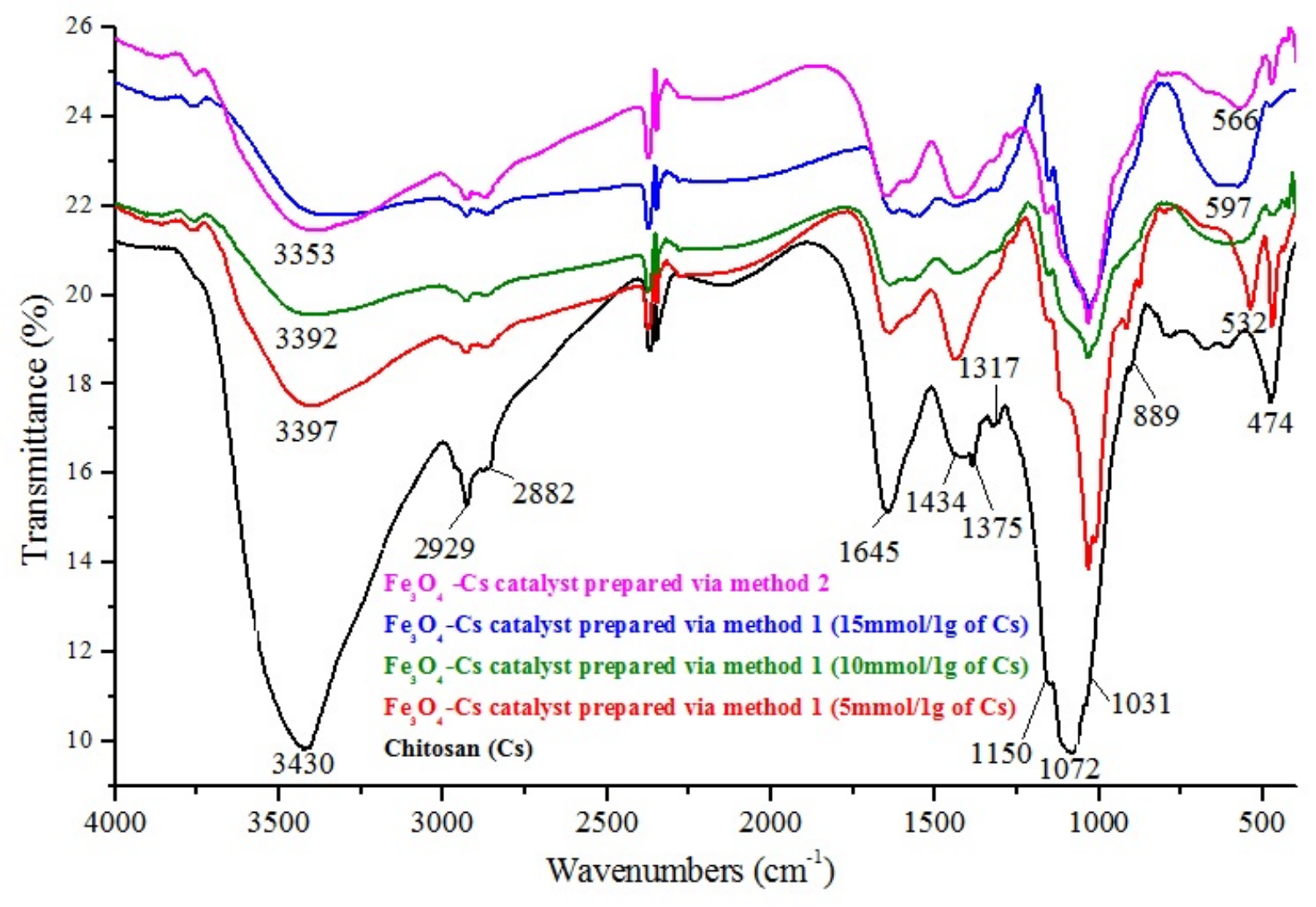

2

Fig.7. FTIR spectra of the used catalysts.

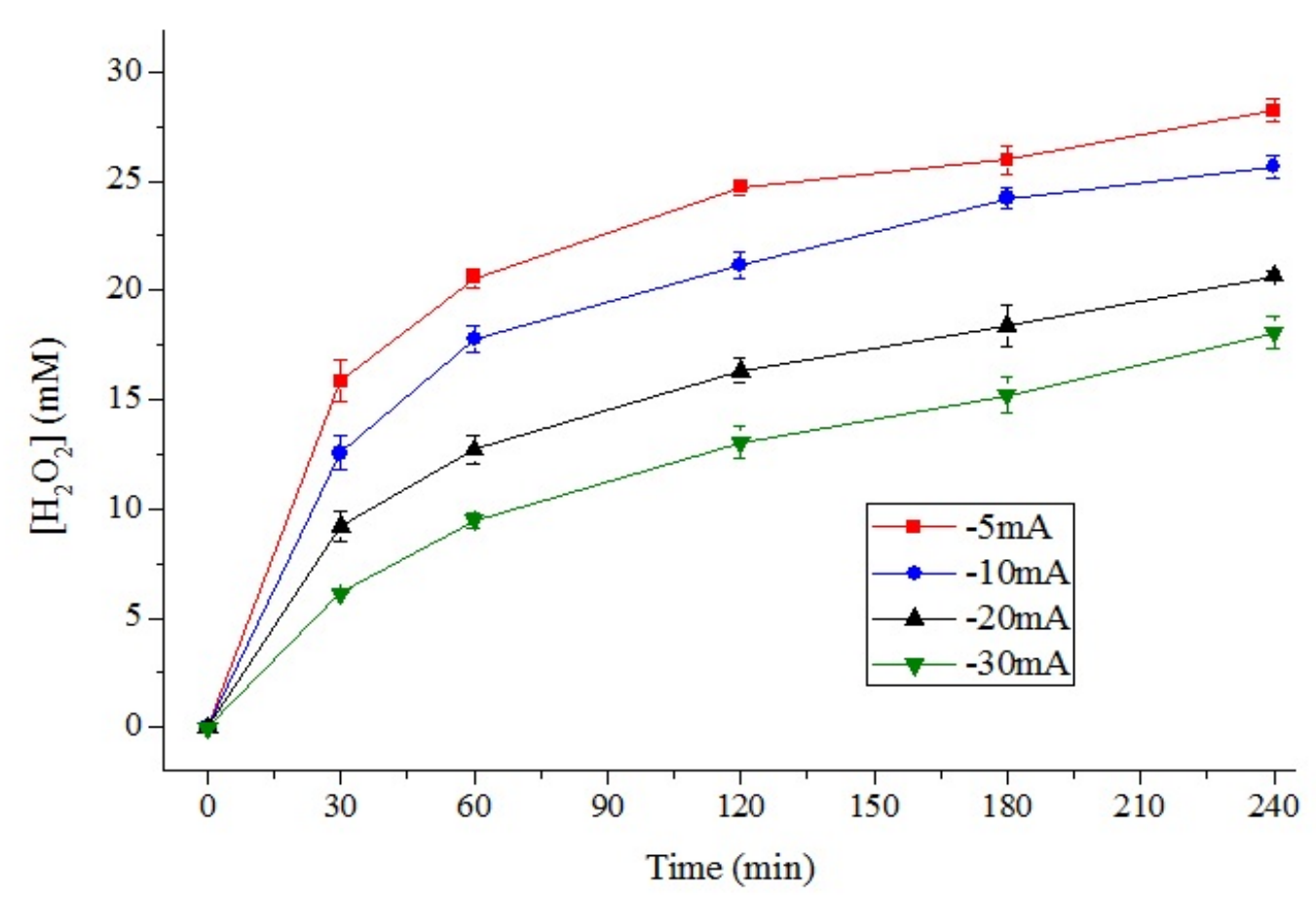

Fig.8. Effect of the applied cathodic current on the change of accumulated hydrogen peroxide concentration with time during electrolysis of $30 \mathrm{~mL}$ of a $0.05 \mathrm{M} \mathrm{Na}_{2} \mathrm{SO}_{4}$ at $\mathrm{pH}=3$. 
1

2 Fig.9. Effect of the current intensity: $[\mathrm{CDM}]=37.5 \mathrm{mg} . \mathrm{L}^{-1} ; \mathrm{pH}=3$; The amount of $\mathrm{Fe} / \mathrm{mass}$ of 3

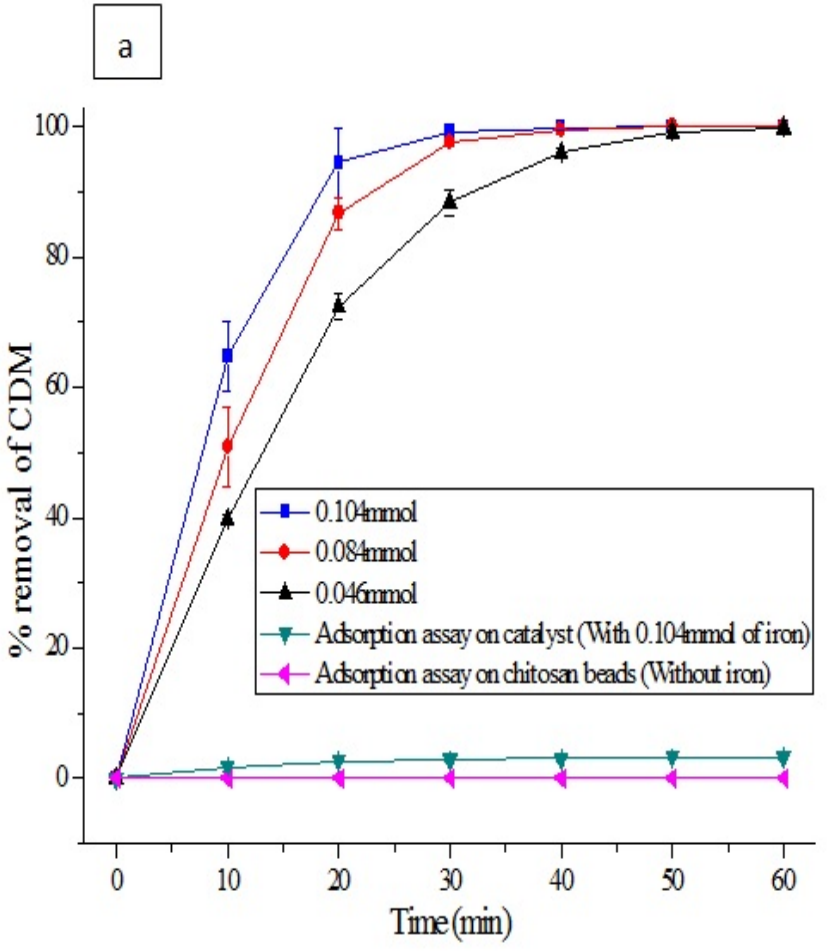
catalyst $=0.083 \mathrm{mmol}$, [catalyst $]=0.5$ g. $\mathrm{L}^{-1}$.

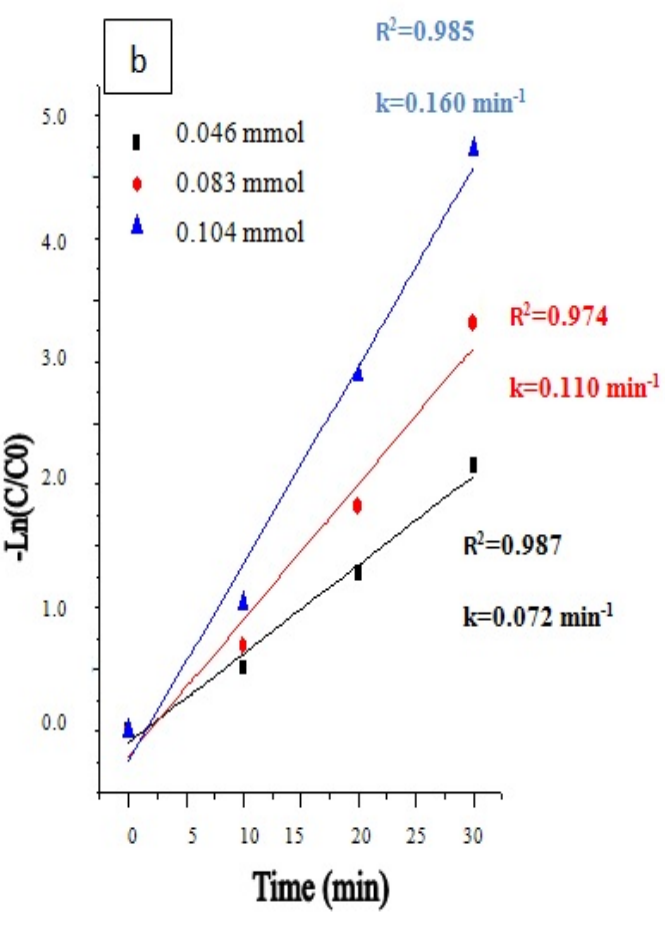

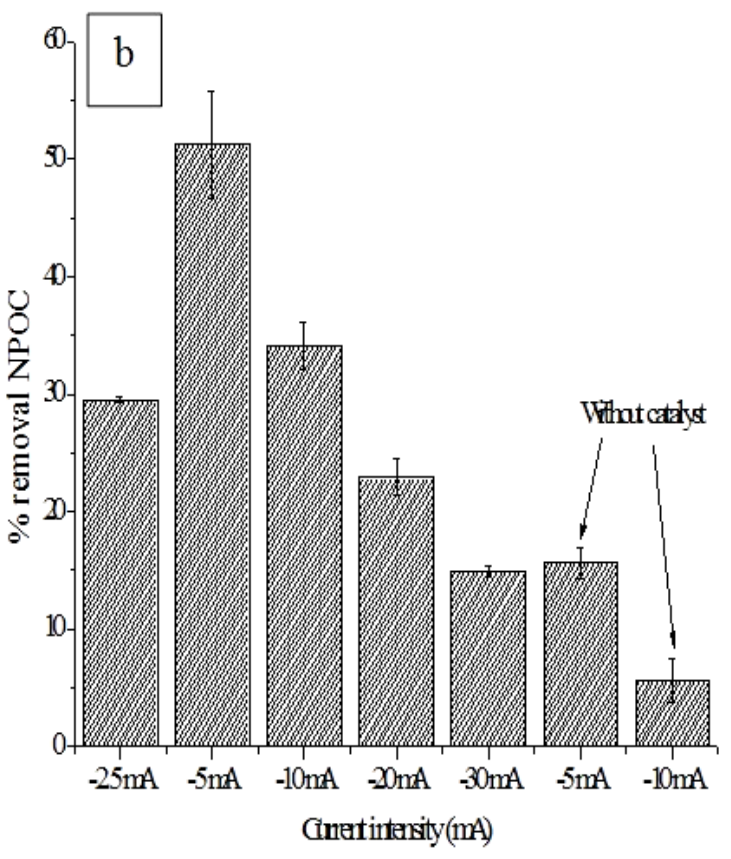

5 Fig.10. Effect of the amount of iron supported in chitosan beads: $[\mathrm{CDM}]=37.5 \mathrm{mg} . \mathrm{L}^{-1}$; $\mathrm{pH}=3$; 

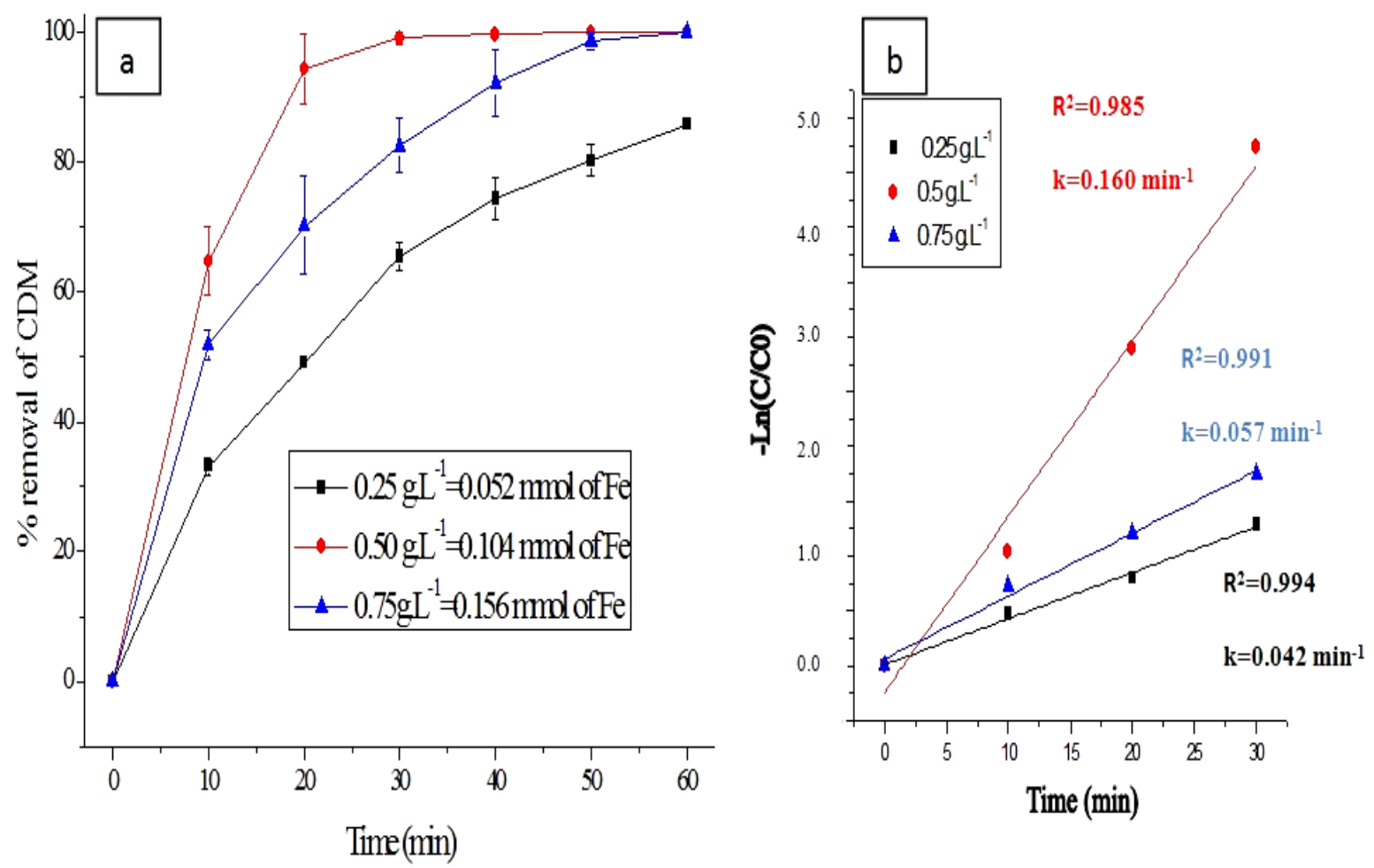

Figure.11. Effect of the concentration of catalyst: $[C D M]=37.5$ mg. $\mathrm{L}^{-1} ; \mathrm{pH}=3$.

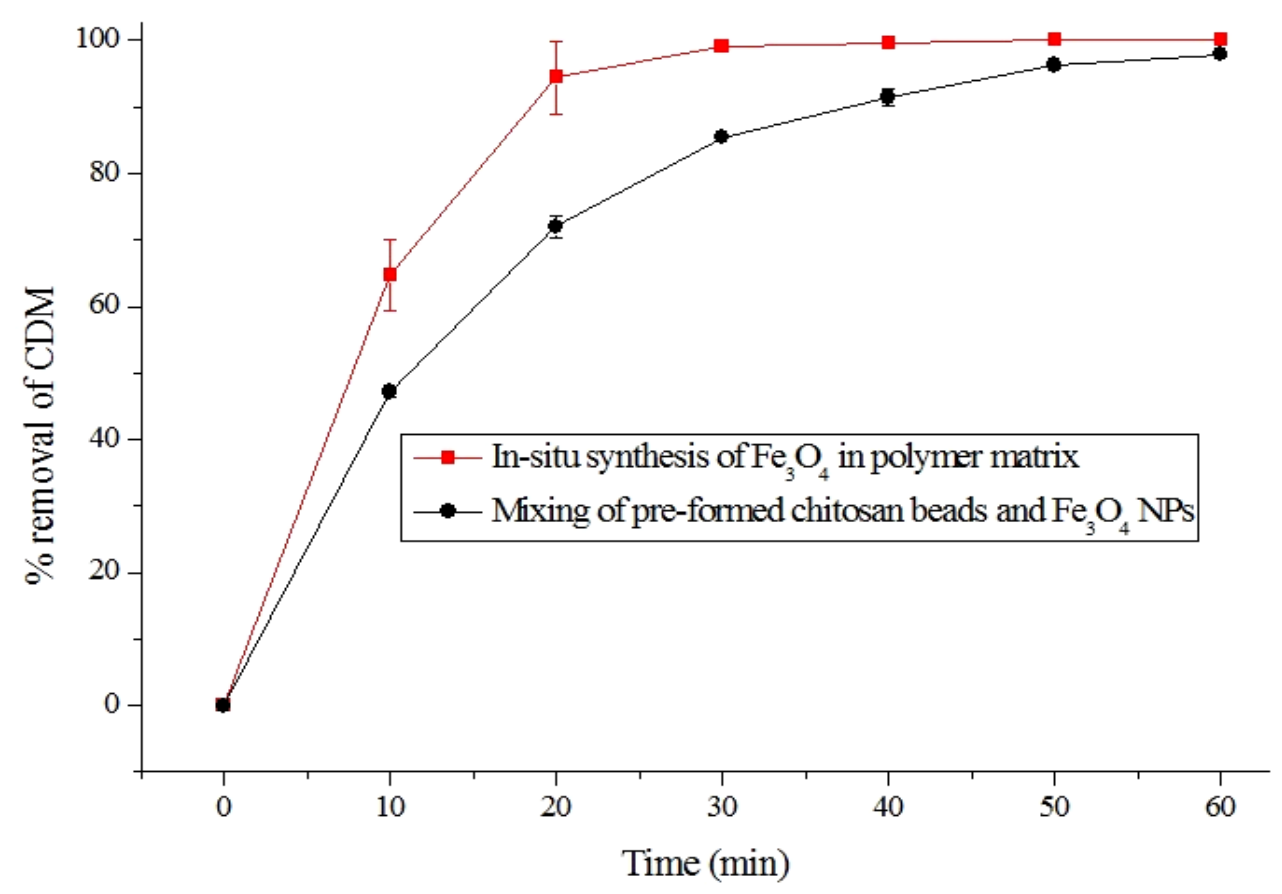

Fig.12. Effect of the preparation method of catalyst: $[\mathrm{CDM}]=37.5 \mathrm{mg} . \mathrm{L}^{-1} ; \mathrm{pH}=3$ and 6 [catalyst $]=0.5$ g. $\mathrm{L}^{1}$. 


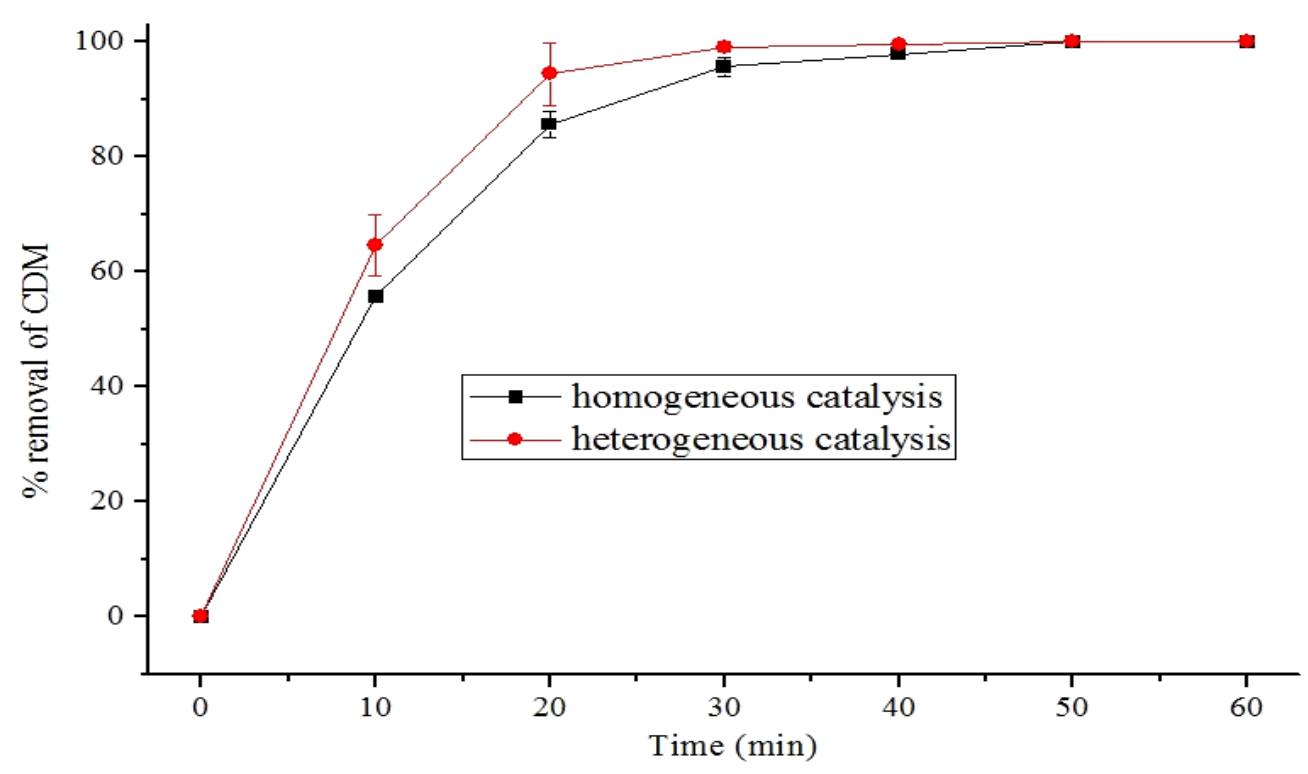

2

3

4

Fig.13. Comparison of heterogeneous and homogeneous electro-Fenton processes:

5

$[\mathrm{CDM}]=37.5 \mathrm{mg} . \mathrm{L}^{-1} ; \mathrm{pH}=3$; [heterogeneous catalyst $]=0.5 \mathrm{~g} . \mathrm{L}^{-1} ;[\mathrm{Fe}($ supported/free $)]=0.1$

6 mmol.

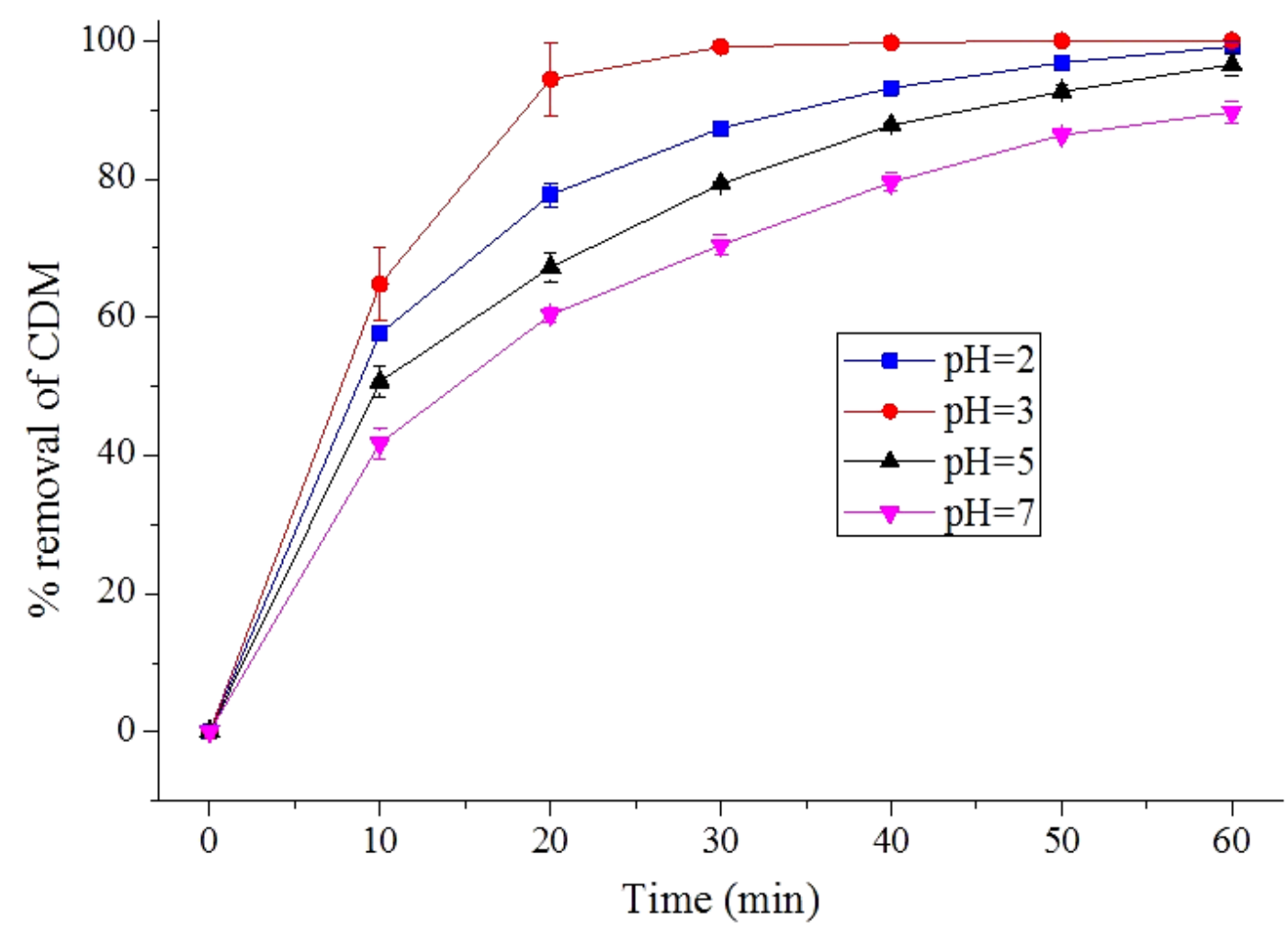

Fig.14. Effect of the $\mathrm{pH}$ on CDM removal by Electro Fenton process using magnetic chitosan beads. 

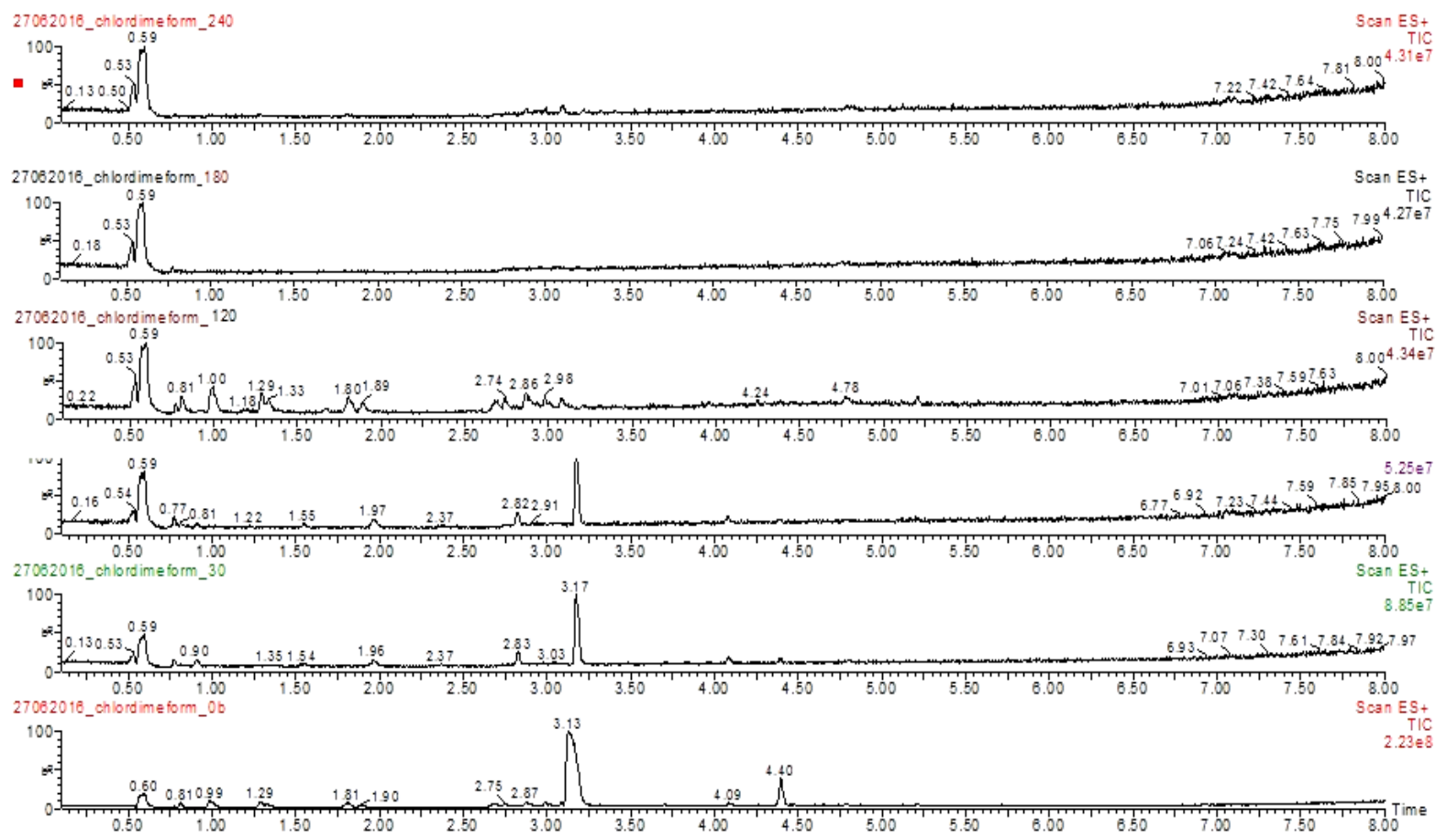

2 Fig.15. LC-MS profiles of chlordimeform obtained during an heterogeneous electro-Fenton

3 process with a working volume of $30 \mathrm{~mL}$, Iimp $=-5 \mathrm{~mA}, \mathrm{pH}=3$ and [catalyst] $=0.5$ g. $\mathrm{L}^{-1}$, $\mathrm{n}_{\mathrm{Fe} / \mathrm{mass}}$

4 of catalyst $=0.104 \pm 0.001 \mathrm{mmoL}$.

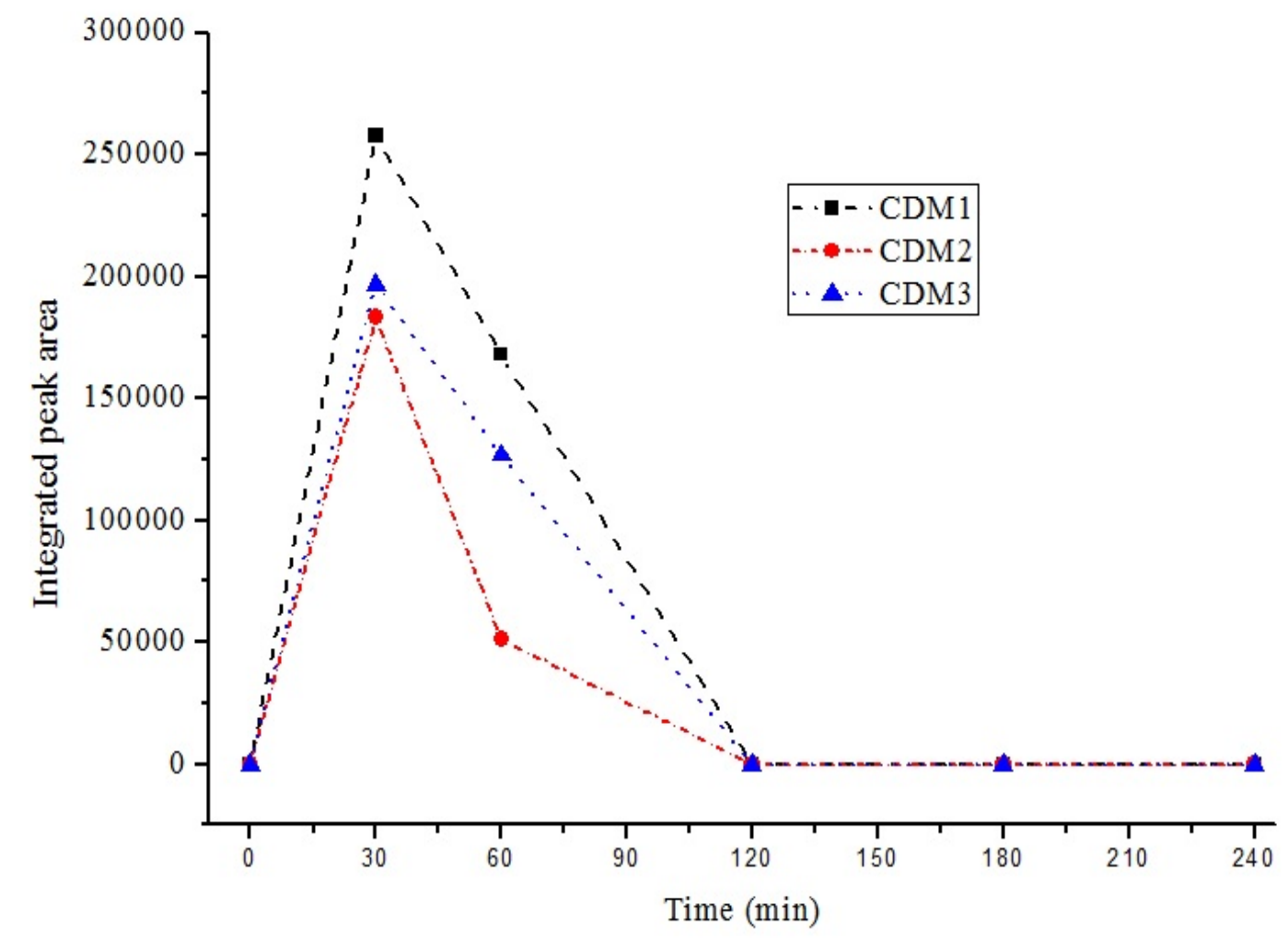

Fig.16. Evolution of selected intermediates during the degradation of CDM under the conditions of Figure 15. 


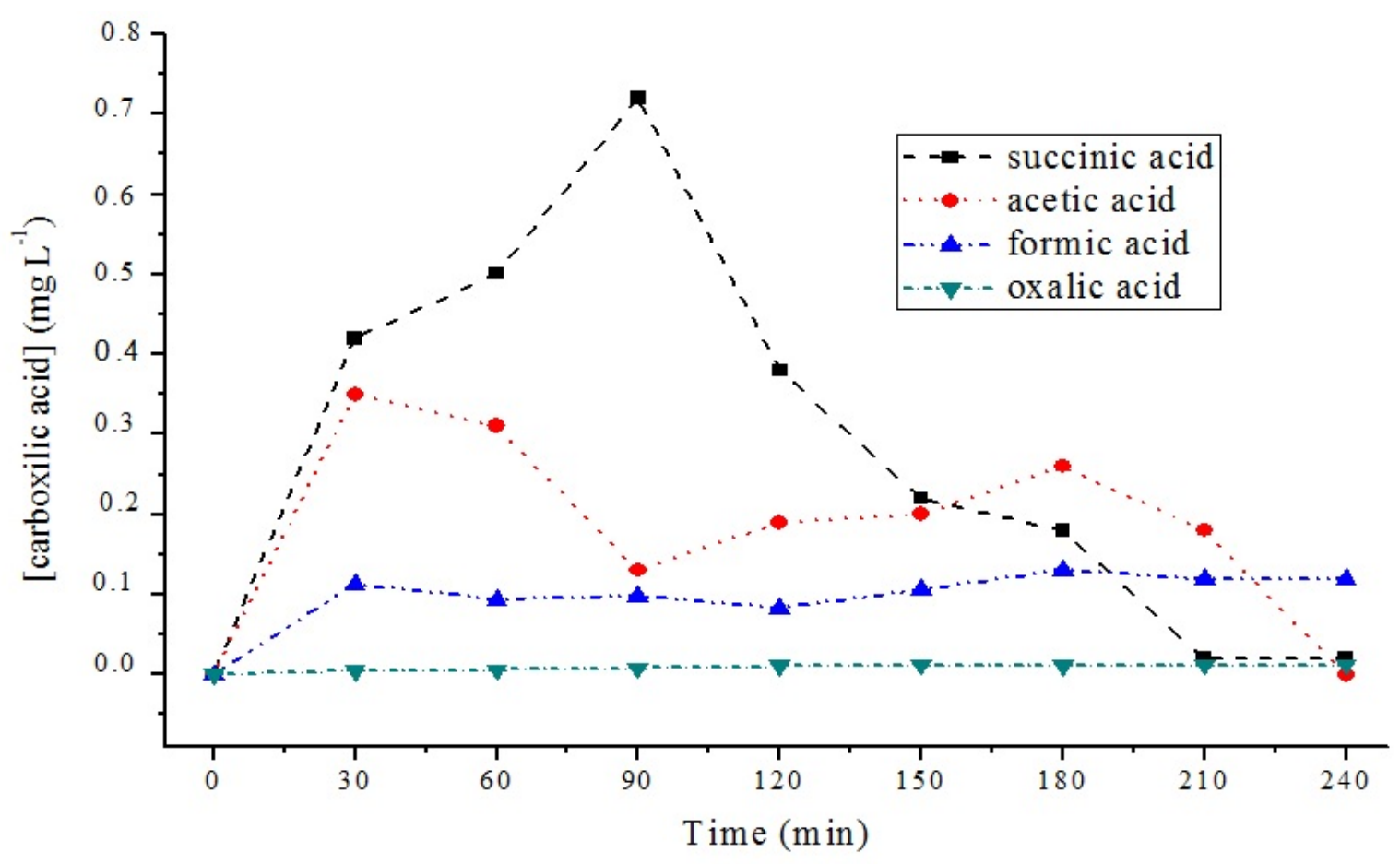

1

2 3

4

Fig.17. Evolution of the formed carboxylic acids during the degradation of CDM under the conditions of Figure 15.

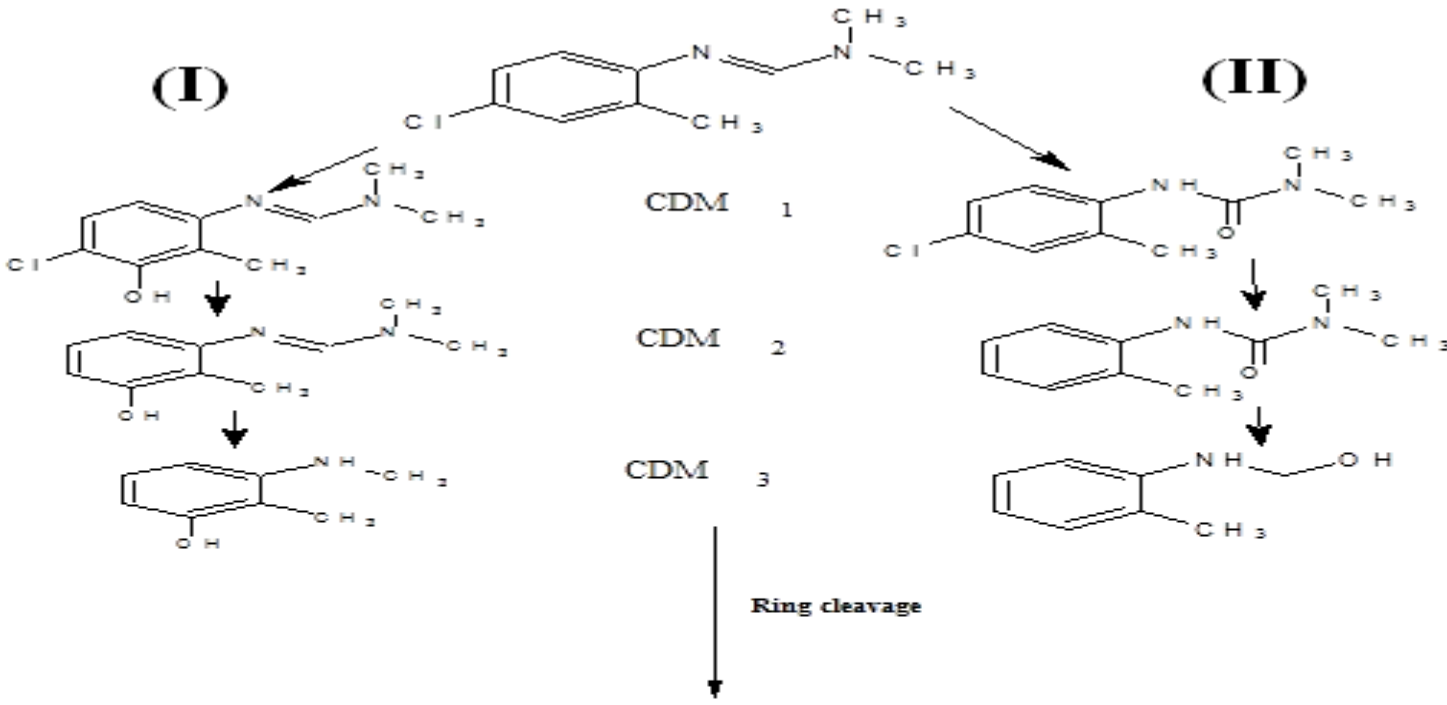<smiles>CC(=O)OC(=O)C(=O)O</smiles>

Fig.18. Plausible degradation pathways of chlordimeform by the heterogeneous Electro-

Fenton process. 

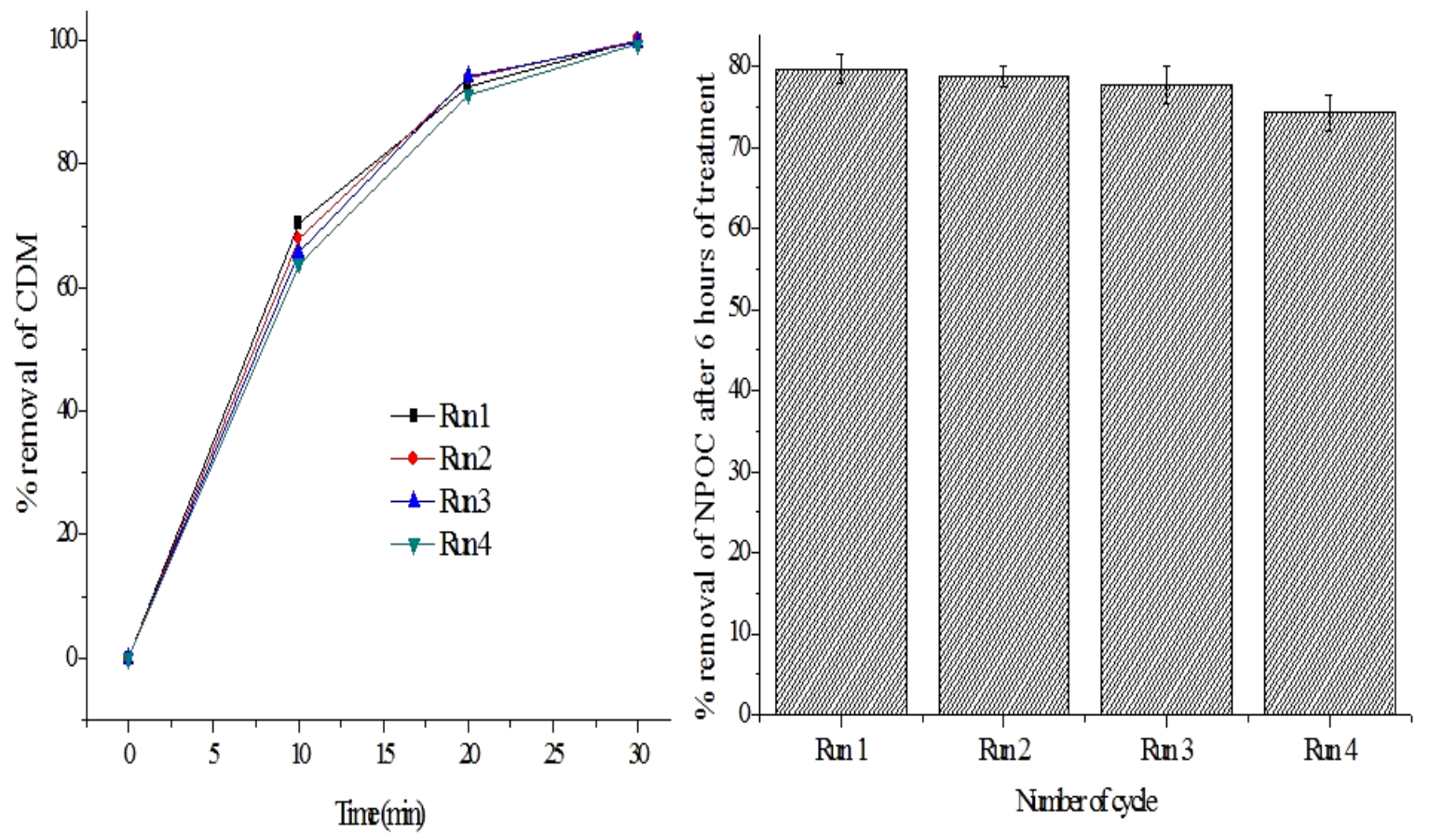

Fig.19. Reusability of the catalyst

\section{$4 \quad$ List of Tables}

5

6 Table.1. The amount of iron in $15 \mathrm{mg}$ mass of catalyst.

\begin{tabular}{|c|c|c|c|c|c|}
\hline \multirow[t]{2}{*}{ Samples } & \multicolumn{3}{|c|}{$\begin{array}{c}\mathrm{Fe}_{3} \mathrm{O}_{4} \text {-Cs beads prepared via method } 1 \\
\text { (amount of iron/1g of Cs) }\end{array}$} & \multirow[t]{2}{*}{ Virgin Cs } & \multirow[t]{2}{*}{$\begin{array}{c}\mathrm{Fe}_{3} \mathrm{O}_{4} \text {-Cs beads } \\
\text { prepared via method } 2\end{array}$} \\
\hline & $5 \mathrm{mmol}$ & $10 \mathrm{mmol}$ & $15 \mathrm{mmol}$ & & \\
\hline$p H$ (zpc) & 7.2 & 7.1 & 7.2 & 7.2 & 7 \\
\hline $\begin{array}{c}\text { [Fe] }(\mathrm{mmoL} / \mathrm{mass} \\
\text { catalyst) }\end{array}$ & $0.046 \pm 0.001$ & $0.083 \pm 0.003$ & $0.104 \pm 0.001$ & 0 & $0.0422 \pm 0.0008$ \\
\hline
\end{tabular}

7

8

9 Table.2. Summary table of mineralization rates for each experiment.

\begin{tabular}{|ccc|}
\hline Parameter & Essay & $\begin{array}{c}\text { \% removal of NPOC } \\
\text { after } \mathbf{6} \text { h of treatment }\end{array}$ \\
\hline \multirow{3}{*}{\begin{tabular}{c} 
The amount of iron per mass of $\begin{array}{c}\text { cotalyst } \\
\text { cataly }\end{array}$ \\
\cline { 2 - 3 }
\end{tabular}} & $0.046 \mathrm{mmol}$ & $61.4 \pm 2.1$ \\
\cline { 2 - 3 } & $0.083 \mathrm{mmol}$ & $70.1 \pm 0.7$ \\
\hline
\end{tabular}




\begin{tabular}{|ccc|}
\hline \multirow{2}{*}{ The catalyst dosage } & 0.25 g.. $\mathrm{L}^{-1}$ & $63.5 \pm 0.8$ \\
\cline { 2 - 3 } & 0.5 g. $\mathrm{L}^{-1}$ & $79.7 \pm 1.7$ \\
\cline { 2 - 3 } The preparation method of catalyst & 0.75 g. $\mathrm{L}^{-1}$ & $71.8 \pm 1.3$ \\
& $\begin{array}{c}\text { In-situ synthesis of } \mathrm{Fe}_{3} \mathrm{O}_{4} \text { on } \\
\text { polymer matrix }\end{array}$ & $79.7 \pm 1.7$ \\
\cline { 2 - 3 } & $\begin{array}{c}\text { Mixing of pre-formed } \mathrm{C}_{\mathrm{S}} \\
\text { beads and } \mathrm{Fe}_{3} \mathrm{O}_{4} \mathrm{NPs}\end{array}$ & $37.8 \pm 2.3$ \\
\hline Type of EF process & Heterogeneous process & $79.7 \pm 1.7$ \\
\hline \multirow{2}{*}{$\mathbf{p H}$} & Homogeneous process & $65.6 \pm 4.2$ \\
\hline & $\mathrm{pH}=3$ & $79.7 \pm 1.7$ \\
\hline & $\mathrm{pH}=7$ & $32.7 \pm 2.3$ \\
\hline
\end{tabular}

1

9 Table.3. LC-MS/MS identification of the chemical formula, retention time and main mass 10 fragmentation values of identified chlordimeform (CDM) intermediates formed during the 11 heterogeneous Electro-Fenton process.

\begin{tabular}{|c|c|c|c|c|}
\hline Compound & Formula & $\operatorname{tr}(\min )$ & $\mathrm{M}\left(\mathrm{g} \cdot \mathrm{mol}^{-1}\right)$ & $\mathrm{m} / \mathrm{z}(\mathrm{ES}+)$ \\
\hline CDM & $\mathrm{C}_{10} \mathrm{H}_{13} \mathrm{ClN}_{2}$ & 3.13 & 196 & 197 \\
\hline CDM 1 & $\mathrm{C}_{10} \mathrm{H}_{13} \mathrm{ClN}_{2} \mathrm{O}$ & 2.83 & 212 & 213 \\
\hline CDM 2 & $\mathrm{C}_{10} \mathrm{H}_{14} \mathrm{~N}_{2} \mathrm{O}$ & 0.90 & 178 & 179 \\
\hline CDM 3 & $\mathrm{C}_{8} \mathrm{H}_{11} \mathrm{NO}$ & 1.97 & 137 & 138 \\
\hline
\end{tabular}

14 Tabele.4. Evolution of the $\mathrm{Fe}^{2+} / \mathrm{Fe}^{3+}$ molar ratio.

\begin{tabular}{|cc|}
\hline Sample & Molar ratio $\mathbf{F e}^{2+} / \mathbf{F e}^{\mathbf{3 +}}$ \\
\hline Cs/iron salts gel solution & $0.517 \pm 0.028$ \\
\hline Wet $\mathrm{Fe}_{3} \mathrm{O}_{4}$-Cs bead & $0.481 \pm 0.001$ \\
\hline Dry $\mathrm{Fe}_{3} \mathrm{O}_{4}$-Cs bead & $0.512 \pm 0.015$ \\
\hline After 6 hours of electrolysis & $0.451 \pm 0.039$ \\
\hline After 12 hours of electrolysis & $0.435 \pm 0.114$ \\
\hline After 18 hours of electrolysis & $0.433 \pm 0.078$ \\
\hline
\end{tabular}


